Article

\title{
Towards Renewable Iodide Sources for Electrolytes in Dye-Sensitized Solar Cells
}

\author{
Iryna Sagaidak ${ }^{1,3}$, Guillaume Huertas ${ }^{1,2,3}$, Albert Nguyen Van Nhien ${ }^{2,3}$ and \\ Frédéric Sauvage ${ }^{1,3, *}$
}

1 Laboratoire de Réactivité et Chimie des Solides, Université de Picardie Jules Verne, CNRS UMR 7314,

33 rue Saint Leu, Amiens 80039, France; iryna.sagaidak@u-picardie.fr (I.S.); guillaumehuertas@free.fr (G.H.)

2 Laboratoire de Glycochimie, des Antimicrobiens et des Agroressources, Université de Picardie Jules Verne, CNRS FRE3517, 33 rue Saint Leu, Amiens 80039, France; albert.nguyen-van-nhien@u-picardie.fr

3 Institut de Chimie de Picardie, FR 3085 CNRS, UFR des Sciences, Université de Picardie Jules Verne, 33 rue Saint Leu, Amiens Cedex 1 80039, France

* Correspondence: frederic.sauvage@u-picardie.fr; Tel.: +33-3-2282-7971

Academic Editor: Claudia Barolo

Received: 13 December 2015; Accepted: 15 March 2016; Published: 26 March 2016

\begin{abstract}
A novel family of iodide salts and ionic liquids based on different carbohydrate core units is herein described for application in dye-sensitized solar cell (DSC). The influence of the molecular skeleton and the cationic structure on the electrolyte properties, device performance and on interfacial charge transfer has been investigated. In combination with the C106 polypyridyl ruthenium sensitizer, power conversion efficiencies lying between $5.0 \%$ and $7.3 \%$ under standard Air Mass (A.M.) 1.5G conditions were obtained in association with a low volatile methoxypropionitrile (MPN)-based electrolyte.
\end{abstract}

Keywords: dye-sensitized solar cells (DSC); ionic liquids; sugar-based iodide sources; liquid electrolyte

\section{Introduction}

The constant population growth combined with the increasing energy dependence raises fundamental questions on how energy can be supplied with the demand expecting to double by 2050 [1]. Energy production is currently dominated by the combustion of fossil fuels (ca. 80\%). The increased awareness of the relationship between fossil fuel burning and greenhouse gas emissions together with the limited crude oil stocks prompt the development of a greener chemistry, synonymous with lower environmental footprints and new energy sources being sustainable and renewable. Solar energy gathers all these criteria to leverage the required energetic transition [2-4]. The deployment of $10 \%$ efficiency photovoltaic panels on $0.1 \%$ of Earth's surface can sustain current humanity needs $\left(10^{14} \mathrm{kWh}\right)[5]$.

However, the intermittent and unpredictable character of solar power requires its hybridization to an external energy storage system capable of stabilizing electricity production and matching the offer with the population's demand. Furthermore, current photovoltaic and battery costs are still not competitive enough compared to fossil fuel combustion. These two drawbacks impede the penetration of solar energy into the current energetic mix. An important impetus towards low cost, low environmental footprint photovoltaics was given by M. Graetzel et al. [6] back in the early 90s, reporting on an efficient dye-sensitized solar cell (DSC) technology based on nanocrystalline anatase $\mathrm{TiO}_{2}$ particles.

Rapidly passing the double digit threshold in 1993 [7], it has recently reached a power conversion efficiency (PCE) of $14.3 \%$ using two different organic dyes combined with $\left[\mathrm{Co}(\mathrm{phen})_{3}\right]^{3+/ 2+}$ redox 
couple [8]. DSC also achieved ca. 10\% stable PCE when combined with low-volatile nitrile solvents under Air Mass (A.M.) $1.5 \mathrm{G}$ conditions $\left(100 \mathrm{~mW} / \mathrm{cm}^{2}\right)[9,10]$.

Although the best conversion performances are nowadays dominated by a series of one electron redox mediator based on cobalt $+\mathrm{III} /+\mathrm{II}$ complexes, the stability still lags far behind the $\mathrm{I}_{3}{ }^{-} / \mathrm{I}^{-}$ redox couple in conjunction with either a low-volatile solvent, e.g., alkoxynitriles [9], sulfolane [11], tetraglyme [12], or in solvent-free binary/ternary eutectic melts, extending the device service lifetime but at the expense of high efficiencies [13]. The source of iodide in the electrolyte is mainly originating from ionic liquids based on the series of 1,3 di-alkyl imidazolium compounds, issued from petroleum derivatives. Other types of cations have been synthesized and incorporated in electrolyte formulation with limited success [13-15]. Attempts to integrate greener solvents for organic PhotoVoltaics (OPV) and greener functionalized imidazolium salts in electrolytes for dye-sensitized solar cells demonstrated the potentialities of these new molecules to even improve some of the properties of the device compared to petroleum derivatives $[16,17]$.

In this work, we report the development of a new series of iodide salts and ionic liquids based on carbohydrate D-glucose or D-mannose core units. Carbohydrates are a family of chemicals among the most abundant natural sources while having benign environmental and health impacts. These novel molecules, incorporated in 3-methoxypropionitrile electrolyte formulation, can exhibit as high as $7.3 \%$ PCE in combination with high molar extinction coefficient $\mathrm{C} 106$ ruthenium dye. The impact of the elimination of the labile anomeric acetal, the influence of the nucleophilic unit, as well as the functionalized hydroxyl group at C-2 on the electrolyte and device performance is herein discussed.

\section{Results and Discussion}

The new iodide-based carbohydrates were included into low-volatile electrolyte composition based on 3-methoxypropionitrile (MPN). The formulation is analogous to the current state-of-the-art in dye-sensitized solar cells enabling to pass ageing tests at $60{ }^{\circ} \mathrm{C} / \mathrm{hv}\left(100 \mathrm{~mW} \cdot \mathrm{cm}^{-2}\right)$ or under $80{ }^{\circ} \mathrm{C} /$ dark conditions [18], namely $1 \mathrm{M}$ of iodide source, $0.15 \mathrm{M}$ of iodine, $0.5 \mathrm{M}$ of $1 \mathrm{H}-\mathrm{N}$ butylbenzimidazole (NBB) and $0.1 \mathrm{M}$ of guanidinium thiocyanate (GuNCS). By way of comparison to current standards, the new electrolytes are permanently referred to the best performing 1,3-dimethylimidazolium iodide (DMII). For the different compounds synthesized, we gathered in Table 1 their main physical characteristics and corresponding properties when solubilized in electrolyte. DMII belongs to the class of ionic liquid compounds having a melting temperature of $93.6{ }^{\circ} \mathrm{C}$ as determined by differential calorimetric measurements. Besides M0(MII) and Ga(MII), which are viscous liquids at room temperature, the other compounds exhibit a melting point lying between $118^{\circ} \mathrm{C}$ for $\mathrm{Ga}(\mathrm{TEA})$ and $140^{\circ} \mathrm{C}$ for M0(TEA). These are consequently purely ionic salts by contrast to all $N, N^{\prime}$-dialkylimidazolium iodide being ionic liquids [19]. These iodide carbohydrates are starting to thermally decompose in air at around $300^{\circ} \mathrm{C}$, thus being thermally stable above the temperature requirements of IEC61646 standard protocol. DSC measurements of the room-temperature liquid M0(MII) and Ga(MII) upon cooling to $-100^{\circ} \mathrm{C}$ did not show evidence of any solidification or crystallization exothermic peak. This observation is not really surprising since many ionic liquids (ILs) have a tendency to show a supercooling effect, owing to extremely slow kinetics of solidification [20]. Upon heating, a broad endothermic glass transition is experienced for which the onset is $-19.1^{\circ} \mathrm{C}$ $\left(\Delta C_{\mathrm{p}}=0.67 \mathrm{~J} / \mathrm{g} \cdot \mathrm{K}\right)$ for $\mathrm{M} 0(\mathrm{MII})$ and $-28.6^{\circ} \mathrm{C}\left(\Delta C_{\mathrm{p}}=0.55 \mathrm{~J} / \mathrm{g} \cdot \mathrm{K}\right)$ for $\mathrm{Ga}(\mathrm{MII})$.

Conductivity and ionic diffusion in electrolytes are two parameters controlled by the viscosity through Nernst-Einstein and Stokes-Einstein relationships [21]. In such kinds of electrolytes, the viscosity is principally dominated by the solvent characteristics for which its intrinsic viscosity is ca. $1.1 \mathrm{cP}$ [22]. When the additives and iodine/iodide redox couple are incorporated, the viscosity increases to $2.10 \mathrm{cP}$ for the benchmark DMII, and up to $3.8 \mathrm{cP}$ for M0(MII). The lowest viscosity is $2.6 \mathrm{cP}$ for the new electrolyte composed of the ionic liquid $\mathrm{Ga}(\mathrm{MII})$. It seems rather difficult to rationalize the relationship between the viscosity and iodide salt structure, as it is often the case with ILs and organic solvents. However, these results tend to suggest that the incorporation of ionic liquid into MPN limits 
the viscosity augmentation. Consequently, the transport properties are the greatest when using DMII. For the latter, ionic conductivity is $7.1 \times 10^{-3} \mathrm{~S} \cdot \mathrm{cm}^{-1}$, the diffusion coefficient $9.4 \times 10^{-4} \mathrm{~cm}^{2} / \mathrm{s}$ for iodide and slower for tri-iodide: $5.0 \times 10^{-5} \mathrm{~cm}^{2} / \mathrm{s}$ determined by $\mathrm{CV}$ and $1.6 \times 10^{-5} \mathrm{~cm}^{2} / \mathrm{s}$ by Electrochemical Impedance Spectroscopy (EIS). Although the two latter methods do not yield to exactly the same values, the trend is not affected. They are also in relatively good concordance with the values reported in the literature so far $[9,15,23-25]$. This result highlights that the diffusion of tri-iodide is kinetically the rate-limiting factor in the transport properties of the electrolytes, as one could expect. Nevertheless, it is remarkable that MII-based carbohydrates are offering ion transport characteristics relatively close to those of DMII; D-glucose being slightly better than D-mannose derivatives (Table 1).

Interestingly, the nature of the cation also influences the charge transfer resistance as expected from its different coordination environment and possibly solvation strength. For the DMII reference sample, we found an $R_{\mathrm{ct}}$ value of $1.70 \Omega \cdot \mathrm{cm}^{2}$. For the new sugar-based molecules, the values are greater, ranging from $2.90 \Omega \cdot \mathrm{cm}^{2}$ for $\mathrm{Ga}(\mathrm{THT})$ to $8.80 \Omega \cdot \mathrm{cm}^{2}$ for M0(MII). Comparing within this new library of materials, it was found that the D-glucose core unit is preferred to the D-mannose counterpart for maintaining low charge transfer resistances. The methoxy $(\mathrm{OMe})$ in anomeric position also diminishes by about two times the charge transfer resistance suggesting a significant role of this group in the charge transfer process.

Chemical stability of the electrolyte was first evaluated in fluorine-doped tin oxide (FTO)-Pt symmetric cells accordingly to IEC61646 protocol at $60{ }^{\circ} \mathrm{C} / 100 \mathrm{~mW} \cdot \mathrm{cm}^{-2}$ for $1000 \mathrm{~h}$ (Figure 1). At room-temperature/ambient conditions, all electrolytes revealed excellent stability properties. When accelerated ageing was carried out using the aforementioned conditions, electrolytes based on D-mannose failed systematically to reach $1000 \mathrm{~h}$ of ageing. All the devices assembled with such electrolytes are degrading, leading to electrolyte leakage after $500 \mathrm{~h}$. Sealing issue cannot be incriminated as all electrolytes based on D-glucose and on $N, N^{\prime}$-dialkylimidazolium iodide never showed such a feature. Consequently, we presume that D-mannose-based electrolytes are not chemically stable with respect to platinum nanoparticles leading to the formation of volatile by-products. This translates into the device (e.g., based on M0(TEA)) on a rapid loss of mass transport coming with an increase in both the charge transfer resistance at transparent conducting oxide (TCO)-Pt interface and electrolyte ohmic drop upon ageing at $60{ }^{\circ} \mathrm{C}$ under $100 \mathrm{~mW} / \mathrm{cm}^{2}$ illumination (Figure 1).

Whereas the initial values for tri-iodide diffusion coefficient were favorable to DMII, upon ageing it is shown that the characteristics of $\mathrm{Ga}$ (THT) and, to a lesser extent $\mathrm{Ga}$ (TEA), can compete with the benchmark. The decrease of charge transfer resistance when using DMII is in good agreement with previous observations and is attributed to the formation of the so-called Solid Electrolyte Interphase (SEI) layer on platinum nanoparticles [26].

The light-to-electricity conversion performances in complete devices have been examined using the hydrophobic ruthenium(+II) polypyril C106 dye. [27] While the DSC assembled with the benchmark electrolyte exhibits a PCE of $8.0 \%$ with $J_{\mathrm{sc}}=16.9 \mathrm{~mA} / \mathrm{cm}^{2}, V_{\mathrm{oc}}=680 \mathrm{mV}$ and ff $=69.3 \%$ (Table 2), we also reached reasonably worthy performances with new electrolytes based on iodide carbohydrates, $\mathrm{PCE}=7.3 \%$ is associated with $\mathrm{Ga}(\mathrm{MII})$ and $\mathrm{GO}(\mathrm{MII}), 6.9 \%$ and $6.7 \%$ for $\mathrm{M} 0$ (TEA) and M0(MII), respectively. More modest performances were obtained with the electrolyte based on Ga(THT) with only $5.0 \%$ PCE resulting from a drop of $100 \mathrm{mV}$ in the photovoltage and a low value of $53.2 \%$ for the fill factor (Table 2). Considering the difficulties for the synthesis of the tetrahydrothiophene to lead to final yield of less than $10 \%$, the results underline that this nucleophilic group does not seem interesting neither in terms of synthesis nor for the application even though the characteristics in TCO-Pt symmetric cell were amongst the most appealing.

As aforementioned, compared to DMII, the main drawback of carbohydrates stems from their low fill factor value, which can be explained by their greater steric hindrance. This contributes to penalizing their intrinsic properties in terms of conductivity, redox diffusion coefficients and ohmic drop. 
Table 1. Values for melting temperature of the new iodide-based carbohydrates and evolution of viscosity, conductivity, $\mathrm{I}_{3}{ }^{-}$and $\mathrm{I}^{-}$diffusion coefficient, charge transfer resistance $\left(\mathrm{R}_{\mathrm{ct}}\right)$ and ohmic drop in related 3-methoxypropionitrile (MPN)-based electrolyte. Note viscosity, conductivity and cyclic voltamperometry (CV) could not get measured for $\mathrm{Ga}(\mathrm{THT})$ owing to the low synthetic yield rendering it difficult to produce enough volume of electrolyte for these analyses (ca. $5 \mathrm{~mL}$ ).

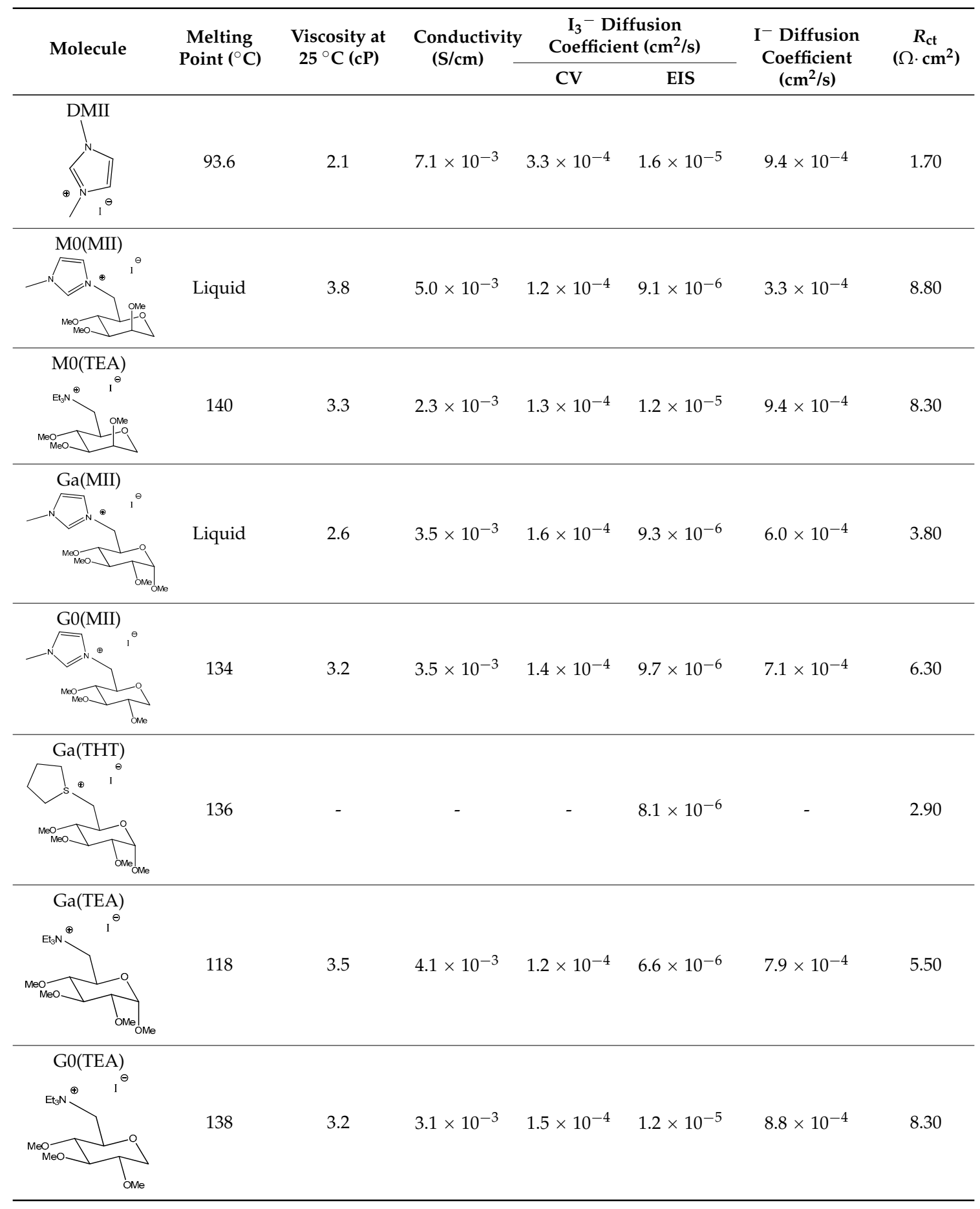




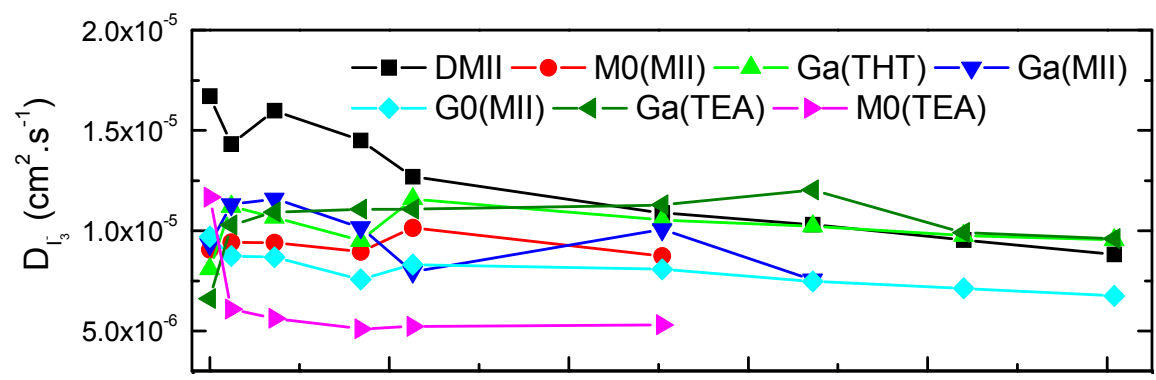

(a)

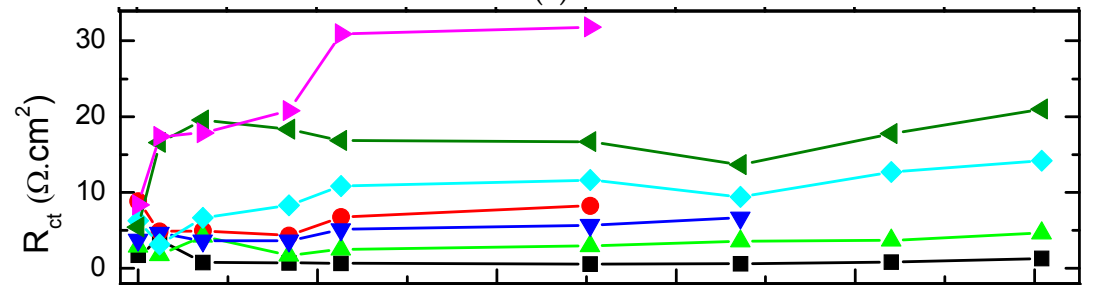

(b)

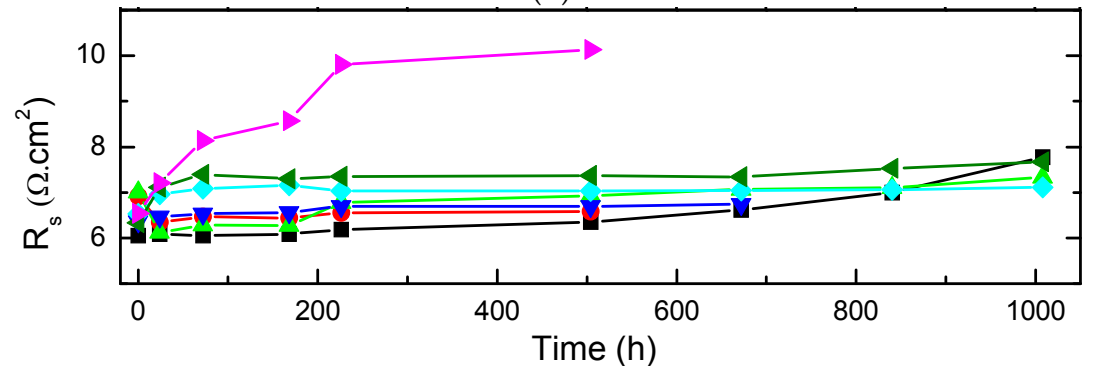

(c)

Figure 1. Evolution of tri-iodide diffusion coefficient (a), charge transfer resistance at counter electrode (CE) (b) and cell ohmic drop (c) as a function of ageing time at $60{ }^{\circ} \mathrm{C}$ under $100 \mathrm{~mW} / \mathrm{cm}^{2}$ light illumination for new iodide-based carbohydrates and compared to the standard DMII.

Table 2. Current-Voltage (J-V) characteristics for C106-sensitized solar cells with the sugar-based electrolytes.

\begin{tabular}{ccccccccc}
\hline Characteristic & Ga(MII) & G0(MII) & M0(TEA) & M0(MII) & Ga(TEA) & G0(TEA) & Ga(THT) & DMII \\
\hline$V_{\mathrm{oc}}(\mathrm{V})$ & 0.696 & 0.698 & 0.656 & 0.701 & 0.680 & 0.650 & 0.581 & 0.680 \\
$J_{\mathrm{sc}}\left(\mathrm{mA} / \mathrm{cm}^{2}\right)$ & 16.2 & 17.5 & 16.6 & 16.9 & 16.5 & 17.1 & 16.1 & 16.9 \\
$\mathrm{ff}(\%)$ & 64.7 & 60.0 & 63.0 & 56.1 & 57.7 & 52.1 & 53.2 & 69.3 \\
$\eta(\%)$ & 7.3 & 7.3 & 6.9 & 6.7 & 6.5 & 5.8 & 5.0 & 8.0 \\
\hline
\end{tabular}

Based on our results, there is no consensual conclusion that can be drawn on whether it is preferable to select D-glucose or D-mannose as a core unit for obtaining high efficiencies. Indeed, whereas D-glucose performs better than the D-mannose in association with the MII nucleophilic group $\left(\eta_{\mathrm{M} 0(\mathrm{MII})}=6.7 \%\right.$ vs. $\left.\eta_{\mathrm{G} 0(\mathrm{MII})}=7.3 \%\right)$, opposite results were obtained in the case of TEA $\left(\eta_{\mathrm{M} 0 \text { (TEA) }}=6.9 \%\right.$ vs. $\left.\eta_{\mathrm{G} 0(\mathrm{TEA})}=5.8 \%\right)$. The results obtained with TEA cation is in a good agreement with the observations made in literature by Graetzel et al. [15], who reported that TEA-based iodide ionic liquids are exhibiting inferior PCE and stability than DMII. Finally, it appears relatively clear from this branch of new molecules that the incorporation of a methoxy group in anomeric position in both cases is beneficial to limit the drop in the fill factor value. At the present stage of electrolyte formulation, we found that electrolytes based on carbohydrates core unit is comparatively less stable than DMII (Figure 2). Regardless of the type of electrolyte, our results show that the degradation rate is faster than in the complete cell. This is in good agreement with our recent report highlighting the harmful role played by the surface of $\mathrm{TiO}_{2}$ on the electrolyte stability when the 3-methoxypropionitrile is 
used as a solvent [26]. The loss of power conversion efficiency during ageing results from a drastic decreases of photocurrent and fill factor. The rate of photovoltage decline seems relatively comparable regardless of the electrolyte, suggesting that the source of iodide seems not playing any role in this loss. It seems again that D-glucose should be preferred for stability over the mannose counterpart. Even though it is likely that carbohydrates-based electrolytes require further optimization in the additive formulation for instance, one can find that cell degradation is faster in our case than in some publications in the literature showing stability with low-volatile MPN-based electrolytes. Note in this case that our ageing experiments were conducted without any external means of UV cut-off filters, which are well-established to prolong the device stability under light stress.

The best efficiencies are obtained with the methylimidazolium nucleophilic cation in association with the D-glucose core unit. From a fundamental point of view, it is worth mentioning that the immobilization of the methylimidazolium unit on sugar allows for the increase of the photovoltage by ca. $20 \mathrm{mV}$ (Figure 3). In order to gain better insight on the origin of this photovoltage increase as well as to better delineate the effect of the carbohydrate structure on the interfacial charge transfer kinetics (recombination and transport), EIS was used to monitor these processes taking place within the millisecond time domain.

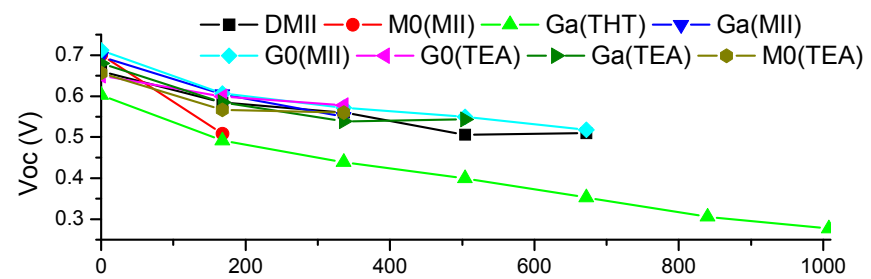

(a)

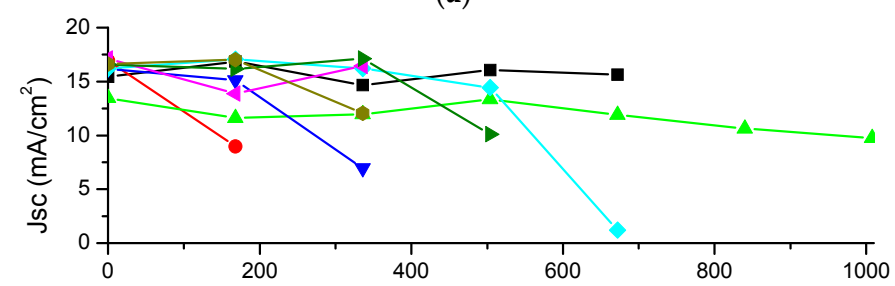

(b)

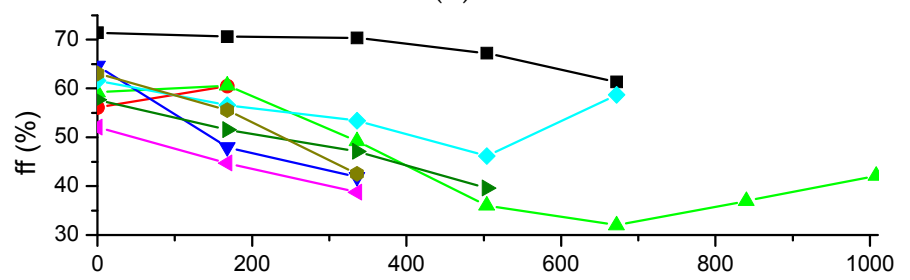

(c)

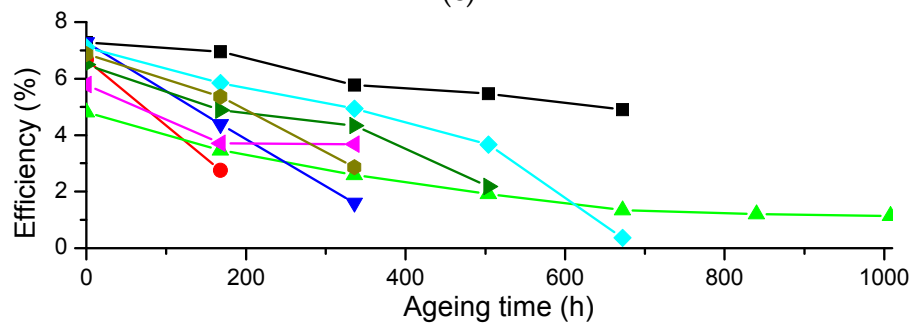

(d)

Figure 2. Evolution of photovoltage (a), photocurrent (b), fill factor (c) and power conversion efficiency (PCE) (d) as a function of ageing time at $60{ }^{\circ} \mathrm{C}$ under $100 \mathrm{~mW} / \mathrm{cm}^{2}$ light illumination without any UV cut-off filters for new iodide-based carbohydrates and compared to the standard DMII. 


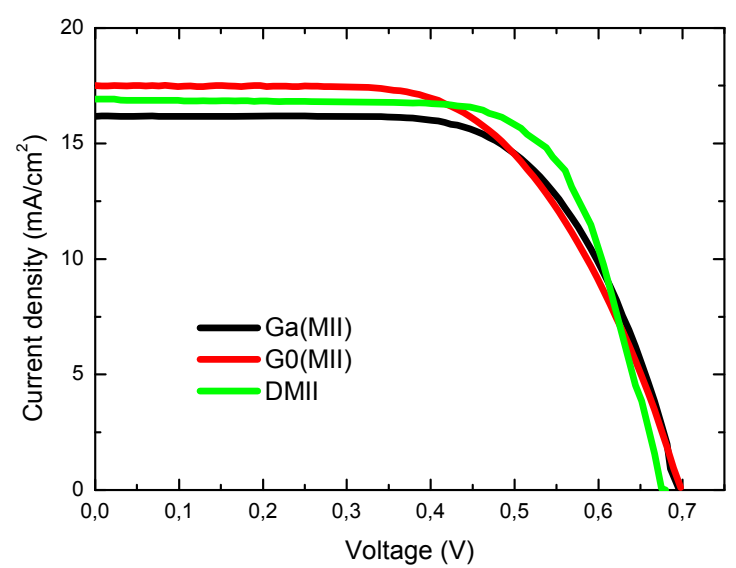

Figure 3. (J-V) characteristics comparison of DSCs with Ga(MII), G0(MII) and DMII electrolytes under standard A.M.1.5G illumination.

In Figure 4, we report the distribution of the trap states, electron lifetime and electron transport time as a function of either applied voltage or density of states (DOS). The DOS is usually determined for suitable interpretation of the electron lifetime and electron transport time in $\mathrm{TiO}_{2}$ as a function of the number of charges in $\mathrm{TiO}_{2}$. This was evaluated from the value of cell capacitance determined by impedance spectroscopy taking into account the geometric factor of the cell according to this relationship [14,28,29]:

$$
\mathrm{DOS}=\frac{6.24 \times 10^{18} \mathrm{C}}{[d(1-p)]}
$$

where $C$ is the film capacitance in $\mathrm{F} / \mathrm{cm}^{2}, d$ and $p$ are the thickness $(\mathrm{cm})$ and porosity of the $\mathrm{TiO}_{2}$ film, respectively. Interestingly, the single exponential distribution and related energy of the intra-band gap trap states depend on the type of iodide source used in the electrolyte. This testifies, as one could expect, to the obvious electrostatic interactions existing between the surface of $\mathrm{TiO}_{2}$ and the electrolyte components. Besides for $\mathrm{Ga}(\mathrm{THT})$, in which the energy of the traps is upshifted by comparison to DMII, the incorporation in electrolyte of iodide carbohydrates induces a slight downshift of the traps. This downshift is the most manifested with MII nucleophilic moiety on D-mannose.

The distribution and energy of the traps partly affect the dynamics of electron recombination and electron transport properties. Interestingly, the type of nucleophilic cation has a significant impact on the electron lifetime. This means that, to some extent, it hampers the electron capture by tri-iodide, likely as a result of its steric hindrance. In contrast, the nucleophilic cation has no or only a little influence on the electron transport process, which is provided by a surface trapping/detrapping mechanism [30]. This is particularly true if we make a comparison at the same DOS (Figure $4 \mathrm{~b}$ ). It has been shown in the literature that this electron surface transport is assisted by an ambipolar diffusion process with electrolyte cations. This seems to demonstrate that the guanidinium cation from the electrolyte controls this ambipolar diffusion in contrast with the nucleophilic cation immobilized on the carbohydrate core unit. Comparing DMII with carbohydrates, specifically those made of MII nucleophilic cation, the gain in electron lifetime is noticeable. It can reach up to one order of magnitude regardless if it as a function of bias voltage or compared at the same DOS. Consequently, the charge collection efficiency is getting improved when using MII-based carbohydrates. The gain of $c a .20 \mathrm{mV}$ in photovoltage and greater photocurrent by immobilizing MII on the carbohydrate core unit is thus explained by this extended electron lifetime/enhanced charge collection efficiency. However, this is not the sole origin since the other carbohydrate molecules showed lower photovoltages, whereas their electron lifetime is also extended, although to a lower level. We can therefore speculate that other faster components are affected such as electron injection rate, dye regeneration or dye excited state lifetime. Finally, the lower electron lifetime of $\mathrm{Ga}$ (THT) leading to the poorer conversion performances 
does not come as a surprise since typically unsaturated cyclic solvent such as the THT is prohibited in photoelectrochemical applications, owing to their strong nucleophilic character tending to capture free electrons yielding to the ring opening [7]. This observation is again a new demonstration that it is needed to avoid the utilization of unsaturated cyclic rings for DSC applications.
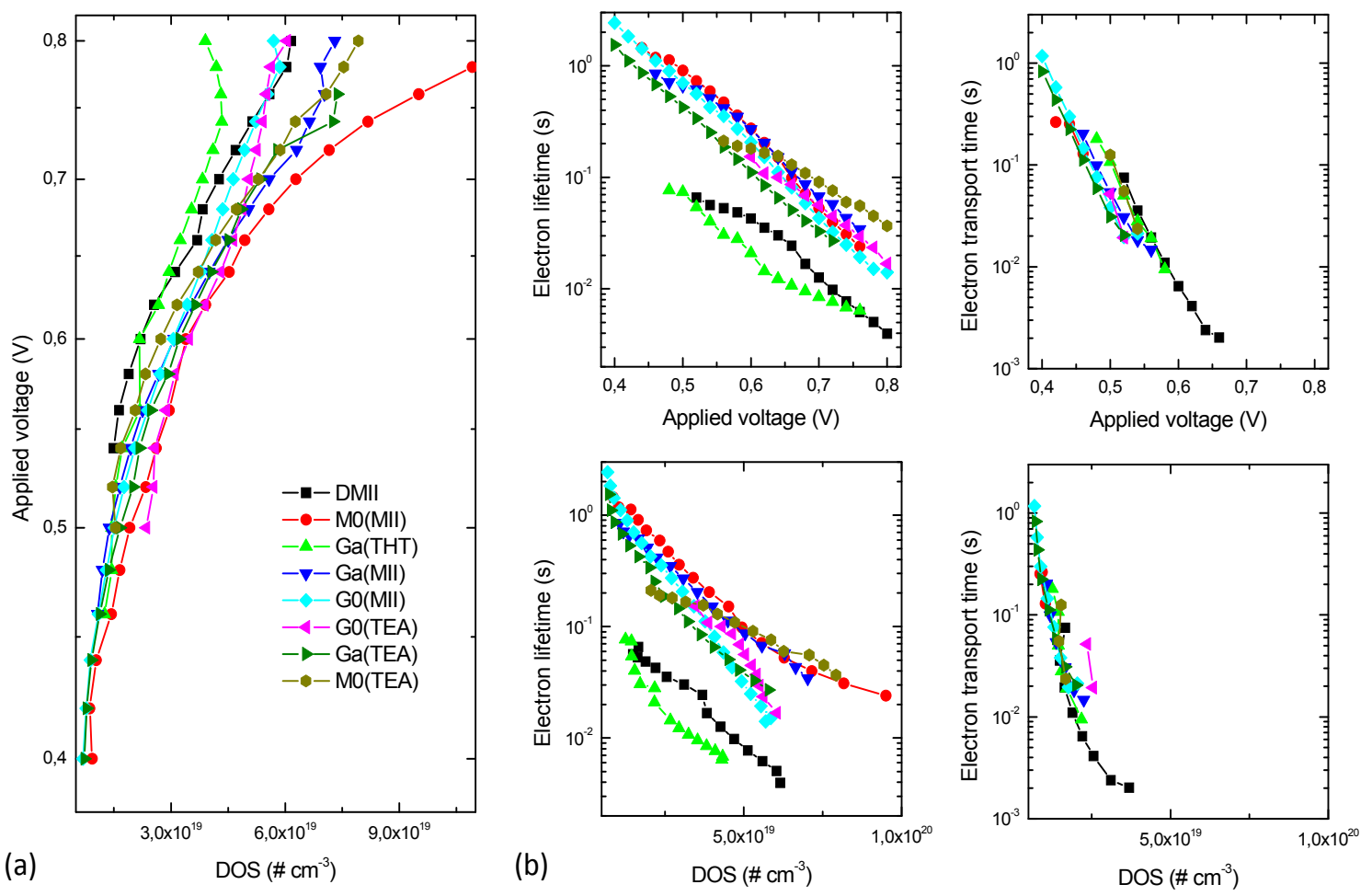

Figure 4. Evolution of trap states distribution; (a) electron lifetime and transport time as a function of applied voltage or density of states (DOS) for the different iodide-based carbohydrates and compared to the standard DMII (b).

\section{Conclusions}

First carbohydrate-based iodide ionic salts and liquids were synthesized from sugar and then successfully integrated as an iodide source in low-volatile electrolyte composition in dye-sensitized solar cells. In conjunction with the C106 ruthenium sensitizer, imidazolium-based D-glucose showed a PCE reaching 7.3\% under standard A.M.1.5G illumination $\left(100 \mathrm{~mW} / \mathrm{cm}^{2}\right)$. The structure of the cation in the electrolyte was found to strongly influence the device performance not only in terms of PCE but also through hindering the dynamics of charge recombination. It has been established in this work, among this new library of materials, that $\mathrm{N}$-methyl-imidazolium cation supported on sugar, regardless if it is D-mannose or D-glucose, enables the improvement of the photovoltage of DSC compared to the benchmark DMII. The combination between D-glucose and its anomeric methoxy group can also increase the photocurrent as a result of enhanced charge collection efficiencies. Nevertheless, these carbohydrates are suffering so far from lower fill factor values. Consequently, their utilization can be beneficial and offer greater PCE under low light flux. Their integration with improved conversion performances calls for the development of a new electrolyte formulation better adapted to this class of molecules, in order to render their stability in complete devices competitive, and also requires the replacement of platinum catalyst to bring them above current standards based on petroleum sources. Although these first results highlight limited stability upon ageing at $60^{\circ} \mathrm{C} / \mathrm{hv}$ conditions, understanding the chemical interplay of these carbohydrates during ageing in dye solar cells will lever up this stability lack and possibly enhance the efficiency of such new types of electrolytes to a similar level with the petroleum derivatives. 


\section{Experimental Section}

All chemicals and solvents were of reagent grade or better, purchased from Aldrich, Acros or Fisher Scientific. The 3-methoxypropionitrile was purchased from Aldrich.

Optical rotations were recorded in $\mathrm{CH}_{2} \mathrm{Cl}_{2}$ solution. ${ }^{1} \mathrm{H}-\mathrm{NMR}(300.13 \mathrm{MHz})$ and ${ }^{13} \mathrm{C}-\mathrm{NMR}$ (75.47 MHz) spectra were recorded in $\mathrm{CDCl}_{3}, \mathrm{DMSO}-d_{6}$ or MeOD- $d_{4}$ (internal $\mathrm{Me}_{4} \mathrm{Si}$ ), respectively. Thin Layer Chromatography (TLC) was performed on Silica F254 and detection was done by UV light at $254 \mathrm{~nm}$ or by charring with the phosphomolybdic- $\mathrm{H}_{2} \mathrm{SO}_{4}$ reagent. Fourier Transform Infra-Red (FT-IR) spectra were obtained on an AVATAR ${ }^{\text {TM }} 320$ neat in attenuated total reflectance (ATR) mode. Mass spectral data were acquired on a WATERS Micromass ZQ spectrometer or a WATERS Micromass Q-TOF spectrometer. Column chromatography was carried out on Silica Gel 60 (230 mesh). Cyclohexane and ethyl acetate were distilled before using.

Thermogravimetric (TGA) and differential scanning calorimetry (DSC) analyses were realized on a Netzsch thermal analyzer STA 449C Jupiter and Netzsch scanning calorimeter DSC 204 F1. TGA was coupled to a mass spectrometer QMS 403 Aëolos with a stainless steel capillary and a SEV detector (Channeltron, for analysis of gas release. The counting time for the mass spectrometer was $20 \mathrm{~ms}$ per $m / z$ values (scanning width: $m / z=10-150 \mathrm{amu}$ ) with a dwelling time of $1 \mathrm{~s}$. The samples $(10-15 \mathrm{mg}$ ) were heated in an alumina crucible until $1000{ }^{\circ} \mathrm{C}$ under air for TGA, and cooled down to $-100{ }^{\circ} \mathrm{C}$ and then heated up to $200^{\circ} \mathrm{C}$ under argon for calorimetric analysis, applying in both cases a heating ramp of $10^{\circ} \mathrm{C} \cdot \mathrm{min}^{-1}$.

The dye-sensitized solar cell assembly was made as follows. Two types of anatase $\mathrm{TiO}_{2}$ layers were deposited by manual screen-printing (Tiflex upon Nippon Sheet Glass (NSG10) FTO glass. The first, of $c a .9 \mu \mathrm{m}$ thickness - $63 \%$ porosity, consisted of nano-sized particles of $20 \mathrm{~nm}$ acidic anatase $\mathrm{TiO}_{2}$. This layer was sheltered by a second of $c a .5 .5 \mu \mathrm{m}$ thickness composed of $400 \mathrm{~nm}$ size anatase particles to back reflect unabsorbed photons in agreement with Mie scattering theory. Prior to screen printing, NSG10 glass was chemically treated by a $0.04 \mathrm{M} \mathrm{TiCl}_{4(\mathrm{aq})}$ solution for $30 \mathrm{~min}$ at $70{ }^{\circ} \mathrm{C}$ to hamper excessive charge recombination from FTO to the electrolyte. A similar procedure has been applied to the post-annealed photo-anode to enhance the charge collection efficiency while reducing the electrode porosity to $c a$. $57 \%$. The electrodes were submitted to a post-annealing treatment to remove terpineol and the binder/porogene accordingly to the literature [31]. Prior to sensitization, the photoanode was heated at $520^{\circ} \mathrm{C}$ for $30 \mathrm{~min}$ in air to remove atmospheric residues adsorbed natively upon $\mathrm{TiO}_{2}$ surface. The photo-anode was then sensitized at room-temperature for $15 \mathrm{~h}$ in dark conditions. The dye utilized is the high molar extinction coefficient heteroleptic ruthenium (+II) C106 dye proposed first by Wang et al. [27]. The dye solution used for sensitization was composed of $300 \mu \mathrm{M}$ of dye in a $1 / 1 v / v$ mixture of tertbutanol/acetonitrile solvent mixture including an equimolar ratio of chenodeoxycholic acid as de-aggregating agent.

TEC7 Pilkington FTO glass was used as a counter electrode. A hole of $c a .200 \mu \mathrm{m}$ in diameter was drilled by sandblasting to enable electrolyte injection by vacuum back-filling. The glass was then cleaned one time for $15 \mathrm{~min}$ in $0.1 \mathrm{M} \mathrm{HCl}$ solution and twice for $15 \mathrm{~min}$ in ethanol using an ultrasonic bath. The counter-electrodes were kept in ethanol until using. A drop of $5 \mathrm{mM} \mathrm{H}_{2} \mathrm{PtCl}_{6}(\mathrm{EtOH})$ solution was cast and heat-treated at $450{ }^{\circ} \mathrm{C}$ for $15 \mathrm{~min}$ in air to yield a layer of $\mathrm{PtO}_{\mathrm{x}}-\mathrm{Pt}$ nanoparticles. The two electrodes were assembled by a $25 \mu \mathrm{m}$ thick transparent Surlyn ${ }^{\circledR}$ gasket polymer DuPont.

Tri-iodide diffusion coefficient and interfacial charge transfer resistance on FTO-Pt electrode were determined using EIS on FTO-Pt/electrolyte/Pt-FTO symmetric cell configuration. The EIS measurements were performed from $200 \mathrm{kHz}$ down to $10 \mathrm{mHz}$ with a superimposed sinusoidal of $10 \mathrm{mV}$ perturbation in the dark at $25^{\circ} \mathrm{C}$ (for both symmetric and DSC devices). The measurements were conducted with a Biologic VMP3 potentiostat/galvanostat/impedancemeter. The EIS data were analyzed using ZView 3.2b software by applying the Randles circuit theory [32]. The diffusion coefficient was determined using the equation $\mathrm{D}_{\mathrm{I}_{3}^{-}}=\mathrm{L}^{2} / \mathrm{W}_{\mathrm{S}}$, where $\mathrm{L}$ corresponds to the separation distance between the two FTO-Pt electrodes and $W_{\mathrm{s}}$ to the Warburg coefficient determined by the fitting analysis of low frequency Nernst diffusion part in the Nyquist plot. All kinetic parameters 
acquired from impedance spectroscopy were determined after simulation with adequate equivalent electrical circuit, e.g., transmission line model for DSC devices [33,34]. Ionic diffusion coefficients were also determined by cyclic-voltammetry using a Pt micro-electrode (limiting current approach).

Photo-current density-voltage (J-V) characteristics of DSCs were recorded by means of a computer controlled digital source meter (Keithley combined with a Newport SOL3A solar simulator (Location) with A.M.1.5G filter. The incident light power was measured by a silicon diode reference cell calibrated at National Renewable Energy Laboratory (NREL). (J-V) characteristics were measured under illumination by changing the bias voltage from short-circuit to open-circuit conditions. The active surface was masked by a black tape with an aperture $1 \mathrm{~mm}$ larger than the $\mathrm{TiO}_{2}$ photo-anode area $\left(0.152 \mathrm{~cm}^{2}\right)$. The PCE values correspond to the best reproducible values obtained. The reproducibility in the values of efficiency obtained is in the range of $c a .0 .1 \%$.

\section{Synthesis}

A denomination was systematically followed to provide a short name to the new carbohydrate molecules. The first letter G stands for D-glucose and M for D-mannose. It is followed by "0" when no methoxy group is present in $\alpha$ position of the anomeric carbon and "a" when there is. The last group represent the short name of the positively charge nucleophilic unit, e.g., MII for 1-methyl-1H-imidazol-3-ium iodide, TEA for $N, N, N$-triethylammonium-iodide, THT for tetrahydro- $1 H$-thiophen-1-ium.

These new functional ionic compounds based on iodide were prepared following a common synthetic approach starting from 1 [35] (Scheme 1) or 3 [36] (Scheme 2). In the first case, iodination was realized by using $\mathrm{PPh}_{3} / \mathrm{I}_{2} /$ Imidazole to afford 2 in $79 \%$ yield. The ionic derivatives G0(MII) and G0(TEA) were obtained respectively by treating 2 in presence of $N$-methylimidazole $(87 \%)$ at $80^{\circ} \mathrm{C}$ or triethylamine at $120^{\circ} \mathrm{C}(71 \%)$.

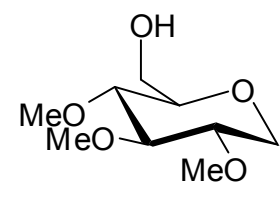

1
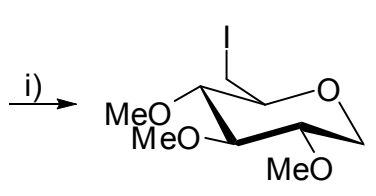

2

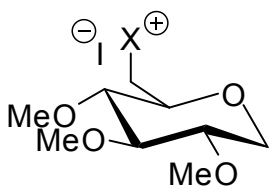

Go(MII) $X=\stackrel{\sqrt{-1}}{N_{1}}$

Go(TEA) $X=\mathrm{Et}_{3} \mathrm{~N}$

reagents and conditions: i) $\mathrm{PPh}_{3}, \mathrm{I}_{2}, \mathrm{C}_{3} \mathrm{H}_{4} \mathrm{~N}_{2}$, toluene, $80^{\circ} \mathrm{C}$, iii) Triethylamine or $\mathrm{N}$-methylimidazole, $80-120^{\circ} \mathrm{C}$.

Scheme 1. Synthesis of new deoxy anomeric D-glucose derivatives G0(MII) and G0(TEA).

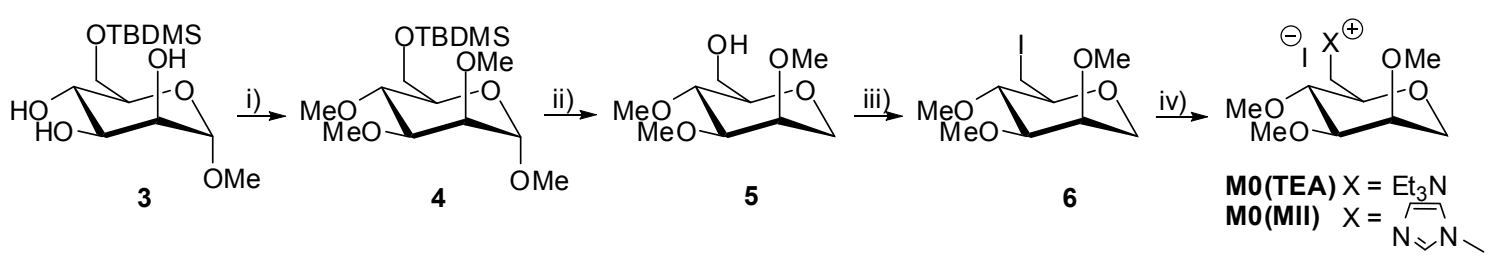

reagents and conditions: i) $\mathrm{NaOH}$, DMSO, Mel, rt., ii) TMSOTf, TES, $\mathrm{CH}_{3} \mathrm{CN}$, iii) $\mathrm{PPh}_{3}, \mathrm{I}_{2}, \mathrm{C}_{3} \mathrm{H}_{4} \mathrm{~N}_{2}$, toluene, $80^{\circ} \mathrm{C}$, iv) Triethylamine or $N$-methylimidazole, $80-120^{\circ} \mathrm{C}$.

Scheme 2. Synthesis of new deoxy anomeric D-mannose derivatives M0(MII) and M0(TEA).

For the D-mannose derivatives, 3 was permethylated with $\mathrm{CH}_{3} \mathrm{I}$ in basic conditions leading to 4 in $61 \%$ yield over two steps. Following Scheme 1, the reduction of the anomeric position to afford 5 as well as the desilvation step was realized by using triethylsilane and trimethylsilyltrifluoromethanesulfonate 
in $78 \%$ yield. The iodide derivative 6 was obtained in 74\% yield. Finally, the ionic D-mannose derivatives M0(TEA) and M0(MII) were obtained in a similar way in 37 and $90 \%$ yield, respectively.

In order to verify the possible influence of the OMe anomeric substituent in the composition of the new electrolyte, we undertook the synthesis of the OMe anomeric D-glucose IL derivatives. Starting from 7 , the iodide derivative 8 was obtained in $61 \%$ yield by using $\mathrm{PPh}_{3} / \mathrm{I}_{2} / \mathrm{Imidazole}$ [37]. The substitution was then realized in the presence of $N$-methylimidazole, triethylamine or tetrahydrothiophene leading to $\mathrm{Ga}(\mathrm{MII}), \mathrm{Ga}(\mathrm{TEA})$ and $\mathrm{Ga}(\mathrm{THT})$ in $91 \%, 80 \%$ and $6 \%$ yield, respectively.

1,6-Dideoxy-6-iodo-2,3,4-trimethoxy-D-glucopyranoside (2). To a solution of $\mathbf{1}(1.00 \mathrm{~g}, 4.85 \mathrm{mmol})$ in toluene $(20 \mathrm{~mL})$ were added $\mathrm{PPh}_{3}(2.55 \mathrm{~g}, 9.7 \mathrm{mmol})$, imidazole $(1.65 \mathrm{~g}, 24.25 \mathrm{mmol})$ and $\mathrm{I}_{2}(2.46 \mathrm{~g}, 9.7 \mathrm{mmol})$ (Scheme 1). After refluxing at $80{ }^{\circ} \mathrm{C}$ overnight, the solvent was eliminated under a vacuum and the reaction mixture purified by flash chromatography (EtOAc/cyclohexane, 30/70 v/v) yielding to compound $2(1.21 \mathrm{~g}, 79 \%)$ as a yellow syrup.

$[\alpha]_{\mathrm{D}}^{20}=+70^{\circ}\left(c=1.78, \mathrm{CH}_{2} \mathrm{Cl}_{2}\right) ; \operatorname{IR}(\mathrm{ATR}): v\left(\mathrm{~cm}^{-1}\right)$ 2933, 2901, 2831, 1461, 1371, 1215, 1165, 1118, 1091, 983, 886; NMR ${ }^{1} \mathrm{H}\left(\mathrm{CD}_{3} \mathrm{OD}, 300 \mathrm{MHz}\right): \delta(\mathrm{ppm}) 3.99\left(\mathrm{dd}, 1 \mathrm{H}, J_{1 \mathrm{a}, 1 \mathrm{~b}}=10.7 \mathrm{~Hz}, \mathrm{~J}_{1 \mathrm{a}, 2}=4.6 \mathrm{~Hz}, \mathrm{H}_{1 \mathrm{a}}\right)$, $3.54(\mathrm{~s}, 3 \mathrm{H}, \mathrm{MeO}), 3.53(\mathrm{~s}, 3 \mathrm{H}, \mathrm{MeO}), 3.39\left(\mathrm{dd}, 1 \mathrm{H}, J_{6 \mathrm{a}, 5}=2.9 \mathrm{~Hz}, J_{6 \mathrm{a}, 6 \mathrm{~b}}=10.7 \mathrm{~Hz}, \mathrm{H}_{6 \mathrm{a}}\right), 3.38(\mathrm{~s}, 3 \mathrm{H}$, $\mathrm{MeO}), 3.28\left(\mathrm{dd}, 1 \mathrm{H}, J_{6 \mathrm{~b}, 5}=5.1, J_{6 \mathrm{~b}, 6 \mathrm{a}}=10.7, \mathrm{H}_{6 \mathrm{~b}}\right), 3.21-3.00\left(\mathrm{~m}, 3 \mathrm{H}, \mathrm{H}_{1 \mathrm{~b}}, \mathrm{H}_{2}, \mathrm{H}_{3}\right) ; \mathrm{NMR}^{13} \mathrm{C}\left(\mathrm{CD}_{3} \mathrm{OD}\right.$, $75 \mathrm{MHz}): \delta(\mathrm{ppm}) 87.4\left(\mathrm{C}_{4}\right), 82.9\left(\mathrm{C}_{3}\right), 79.9\left(\mathrm{C}_{5}\right), 77.5\left(\mathrm{C}_{2}\right), 67.2\left(\mathrm{C}_{1}\right), 60.8(\mathrm{OMe}), 60.6(\mathrm{OMe}), 58.7$ $(\mathrm{OMe}), 7.54\left(\mathrm{C}_{6}\right)$; High Resolution Mass Spectrometry (HRMS) calculated for $\mathrm{C}_{9} \mathrm{H}_{17} \mathrm{IO}_{4} \mathrm{Na}$ : 339.0073 , found 339.0069 .

1,6-Dideoxy-6-(1-methyl-1H-imidazol-3-ium iodide)-2,3,4-trimethoxy-D-glucopyranoside (G0(MII)). $\mathrm{N}$-methylimidazole $(0.80 \mathrm{~mL}, 6.7 \mathrm{mmol})$ was added to compound $2(2.12 \mathrm{~g}, 6.7 \mathrm{mmol})$ and the reaction mixture stirred for $24 \mathrm{~h}$ at $80^{\circ} \mathrm{C}$. $\mathrm{N}$-methylimidazole was eliminated under a vacuum, the reaction mixture was dispersed into ethyl acetate under ultrasound and filtrated yielding to the compound coded G0(MII) $(2.33 \mathrm{~g}, 87 \%)$ as a yellow powder (Scheme 1).

$[\alpha]_{\mathrm{D}}^{20}=+15^{\circ}\left(c=0.12, \mathrm{CH}_{2} \mathrm{Cl}_{2}\right)$; IR(ATR): $v\left(\mathrm{~cm}^{-1}\right) 3458(\mathrm{~L}), 3088,3041,2938,2894,1575,1180,1143,1097$, 1051, 984, 743; $\mathrm{NMR}^{1} \mathrm{H}\left(\mathrm{CD}_{3} \mathrm{OD}, 300 \mathrm{MHz}\right): \delta(\mathrm{ppm}) 9.74(\mathrm{~s}, 1 \mathrm{H}, \mathrm{CH}=\mathrm{N}), 7.46\left(\mathrm{t}, 1 \mathrm{H}, J_{\mathrm{CH}=\mathrm{CH}}=1.8 \mathrm{~Hz}\right.$, $\mathrm{CH}=\mathrm{CH}), 7.30\left(\mathrm{t}, 1 \mathrm{H}, \mathrm{J}_{\mathrm{CH}=\mathrm{CH}}=1.8 \mathrm{~Hz}, \mathrm{CH}=\mathrm{CH}\right), 4.58\left(\mathrm{dd}, 1 \mathrm{H}, \mathrm{J}_{6 \mathrm{a}, 6 \mathrm{~b}}=14.3 \mathrm{~Hz}, \mathrm{~J}_{6 \mathrm{a}, 5}=2.4 \mathrm{~Hz}, \mathrm{H}_{6 \mathrm{a}}\right)$, $4.27\left(\mathrm{dd}, 1 \mathrm{H}, J_{6 \mathrm{~b}, 6 \mathrm{a}}=14.3 \mathrm{~Hz}, J_{6 \mathrm{~b}, 5}=8.2 \mathrm{~Hz}, \mathrm{H}_{6 \mathrm{~b}}\right), 4.12\left(\mathrm{~s}, 3 \mathrm{H}, \mathrm{NCH}_{3}\right), 4.02\left(\mathrm{dd}, 1 \mathrm{H}, J_{1 \mathrm{a}, 1 \mathrm{~b}}=11.1 \mathrm{~Hz}\right.$, $\left.J_{1 \mathrm{~b}, 2}=4.6 \mathrm{~Hz}, \mathrm{H}_{1 \mathrm{~b}}\right), 3.57(\mathrm{~s}, 3 \mathrm{H}, \mathrm{OMe}), 3.56(\mathrm{~s}, 3 \mathrm{H}, \mathrm{OMe}), 3.41(\mathrm{~s}, 3 \mathrm{H}, \mathrm{OMe}), 3.40\left(\mathrm{~m}, 1 \mathrm{H}, J_{6 \mathrm{a}, 5}=2.4 \mathrm{~Hz}\right.$, $\left.J_{6 \mathrm{~b}, 5}=8.2 \mathrm{~Hz}, \mathrm{H}_{5}\right), 3.21\left(\mathrm{dd}, 1 \mathrm{H}, J_{1 \mathrm{~b}, 2}=4.6 \mathrm{~Hz}, J_{2,3}=8.6 \mathrm{~Hz}, \mathrm{H}_{2}\right), 3.15\left(\mathrm{dd}, 1 \mathrm{H}, J_{6 \mathrm{a}, 5}=2.4 \mathrm{~Hz}, \mathrm{H}_{4}\right), 3.06$ $\left(\mathrm{dd}, 1 \mathrm{H}, J_{1 \mathrm{a}, 1 \mathrm{~b}}=11.1 \mathrm{~Hz}, \mathrm{H}_{1 \mathrm{a}}\right), 2.79\left(\mathrm{dd}, 1 \mathrm{H}, J_{3,2}=8.6 \mathrm{~Hz}, \mathrm{H}_{3}\right) ; \mathrm{NMR}^{13} \mathrm{C}\left(\mathrm{CD}_{3} \mathrm{OD}, 75 \mathrm{MHz}\right): \delta(\mathrm{ppm})$ $137.5(\mathrm{~N}=\mathrm{C}), 123.8(\mathrm{C}=\mathrm{C}), 123.1(\mathrm{C}=\mathrm{C}), 87.2\left(\mathrm{C}_{4}\right), 80.1\left(\mathrm{C}_{3}\right), 79.7\left(\mathrm{C}_{5}\right), 77.0\left(\mathrm{C}_{2}\right), 67.5\left(\mathrm{C}_{1}\right), 60.9,60.7$, 58.9 (3 x OMe), $51.3\left(\mathrm{C}_{6}\right), 37.5$ (Me-N); MS(ESI): $\left[\mathrm{M}^{-}\right]=126.1 \mathrm{~m} / z$; HRMS calculated for $\mathrm{C}_{13} \mathrm{H}_{23} \mathrm{~N}_{2} \mathrm{O}_{4}$ : 271.1657, found 271.1658 .

1,6-Dideoxy-6-(N,N,N-triethylammonium-iodide)-2,3,4-trimethoxy-D-glucopyranoside

(GO(TEA)). Triethylamine $(2.39 \mathrm{~mL}, 17.8 \mathrm{mmol})$ was added to compound $2(0.51 \mathrm{~g}, 1.6 \mathrm{mmol})$ and the reaction mixture stirred overnight at $120^{\circ} \mathrm{C}$. After removal of the solvent, diethyl ether was added and the reaction mixture was sonicated for $5 \mathrm{~min}$. After filtration, the retrieved solid was washed with ethyl ether to remove traces of unreacted precursor yielding to the new compound coded G0(TEA) $(0.48 \mathrm{~g}, 71 \%)$ as a light yellow powder (Scheme 1$)$.

$[\alpha]_{\mathrm{D}}^{20}=+63^{\circ}\left(c=0.16, \mathrm{CH}_{2} \mathrm{Cl}_{2}\right) ; \operatorname{IR}(\mathrm{ATR}): v\left(\mathrm{~cm}^{-1}\right) 2974,2945,1450,1404,1142,1118,1098,1065,1046$, 990, 888, 789; $\mathrm{NMR}^{1} \mathrm{H}\left(\mathrm{CD}_{3} \mathrm{OD}, 300 \mathrm{MHz}\right): \delta(\mathrm{ppm}) 3.97\left(\mathrm{dd}, 1 \mathrm{H}, J_{1 \mathrm{a}, 2}=4.4 \mathrm{~Hz}, J_{1 \mathrm{a}, 1 \mathrm{~b}}=11.3 \mathrm{~Hz}\right.$, $\left.\mathrm{H}_{1 \mathrm{a}}\right), 3.71\left(\mathrm{dd}, 1 \mathrm{H}, J_{3,4}=8.9 \mathrm{~Hz}, J_{4,5}=4.8 \mathrm{~Hz}, \mathrm{H}_{4}\right), 3.63,3.61,3.44(\mathrm{~s}, 9 \mathrm{H}, 3 \times \mathrm{OMe}), 3.63-3.44(\mathrm{~m}$, $\left.8 \mathrm{H}, 3 \times \mathrm{NCH}_{2}, \mathrm{H}_{6 \mathrm{a}}, \mathrm{H}_{6 \mathrm{~b}}\right), 3.34\left(\mathrm{t}, 1 \mathrm{H}, J_{1 \mathrm{a}, 1 \mathrm{~b}}=J_{1 \mathrm{~b}, 2}=11.3 \mathrm{~Hz}, \mathrm{H}_{1 \mathrm{~b}}\right), 3.21\left(\mathrm{~m}, 2 \mathrm{H}, \mathrm{H}_{2}, \mathrm{H}_{3}\right), 1.38(\mathrm{t}, 9 \mathrm{H}$, $\left.J_{\mathrm{CH} 2, \mathrm{CH} 3}=7.2 \mathrm{~Hz}, 3 \times \mathrm{CH}_{3}\right) ; \mathrm{NMR}^{13} \mathrm{C}\left(\mathrm{CD}_{3} \mathrm{OD}, 75 \mathrm{MHz}\right): \delta(\mathrm{ppm}) 87.4\left(\mathrm{C}_{2}\right), 80.2\left(\mathrm{C}_{3}\right), 79.4\left(\mathrm{C}_{5}\right), 73.2$ $\left(\mathrm{C}_{4}\right), 67.1\left(\mathrm{C}_{1}\right), 61.3(\mathrm{OMe}), 60.6(\mathrm{OMe}), 58.7(\mathrm{OMe}), 58.8\left(\mathrm{C}_{6}\right), 54.6\left(3 \times \mathrm{NCH}_{2}\right), 79\left(3 \times \mathrm{CH}_{3}\right) ; \mathrm{MS}(\mathrm{ESI})$ : $\left[\mathrm{M}^{-}\right]=126.1 \mathrm{~m} / z$; HRMS calculated for $\mathrm{C}_{15} \mathrm{H}_{32} \mathrm{NO}_{4}$ : 290.2331, found 290.2331. 
6-O-Tertbutyldimethylsilyl-1,2,3,4-tetramethoxy- $\alpha$-D-mannopyranoside (4). To a solution of 3 (1.0 g, $3.24 \mathrm{mmol})$ in THF $(20 \mathrm{~mL})$ at $0{ }^{\circ} \mathrm{C}$ was added $\mathrm{NaH} 60 \%(0.47 \mathrm{~g}, 19.48 \mathrm{mmol})$. After stirring for $1 \mathrm{~h}, \mathrm{CH}_{3} \mathrm{I}(2.77 \mathrm{~g}, 19.48 \mathrm{mmol})$ is added to the reaction mixture and left under stirring at room temperature overnight. After careful neutralization of $\mathrm{NaH}$ with water, the reaction mixture was extracted twice with $\mathrm{CH}_{2} \mathrm{Cl}_{2}$. The organic phase was dried over $\mathrm{Na}_{2} \mathrm{SO}_{4}$, filtered and the solvent eliminated under reduced pressure. After flash chromatography purification (cyclohexane/ethyl acetate, $70 / 30, v / v)$, compound $4(0.47 \mathrm{~g}, 42 \%)$ was isolated as a colorless syrup (Scheme 2$)$.

$[\alpha]_{\mathrm{D}}^{20}=+49^{\circ}\left(c=0.94, \mathrm{CH}_{2} \mathrm{Cl}_{2}\right) ; \operatorname{IR}(\mathrm{ATR}): v\left(\mathrm{~cm}^{-1}\right) 2951,2928,2905,2856,1251,1190,1129,1110,1101$, 1063, 1018, 967, 833, 775, 677; NMR ${ }^{1} \mathrm{H}\left(\mathrm{CD}_{3} \mathrm{OD}, 300 \mathrm{MHz}\right): \delta(\mathrm{ppm}) 4.71\left(\mathrm{~s}, 1 \mathrm{H}, \mathrm{H}_{1}\right), 3.71\left(\mathrm{~s}, 2 \mathrm{H}, \mathrm{H}_{6}\right)$, $3.52\left(\mathrm{~m}, 2 \mathrm{H}, \mathrm{H}_{2}, \mathrm{H}_{4}\right), 3.50$ (s, $\left.3 \mathrm{H}, \mathrm{OMe}\right), 3.46$ (s, $\left.3 \mathrm{H}, \mathrm{OMe}\right), 3.43$ (s, $\left.3 \mathrm{H}, \mathrm{OMe}\right), 3.40\left(\mathrm{~m}, 2 \mathrm{H}, \mathrm{H}_{3}, \mathrm{H}_{5}\right)$, 3.33 (s, $3 \mathrm{H}, \mathrm{OMe}), 0.84(\mathrm{~s}, 9 \mathrm{H}, t \mathrm{Bu}), 0.01\left(\mathrm{~s}, 6 \mathrm{H}, \mathrm{SiMe}_{2}\right)$; NMR ${ }^{13} \mathrm{C}\left(\mathrm{CD}_{3} \mathrm{OD}, 75 \mathrm{MHz}\right): \delta(\mathrm{ppm}) 97.5$ $\left(\mathrm{C}_{1}\right), 81.5,77.2,76.5,73.2\left(\mathrm{C}_{2}, \mathrm{C}_{3}, \mathrm{C}_{4}, \mathrm{C}_{5}\right), 62.9\left(\mathrm{C}_{6}\right), 60.9(\mathrm{OMe}), 58.7(\mathrm{OMe}), 57.8(\mathrm{OMe}), 54.8(\mathrm{OMe})$, $25.1(t \mathrm{Bu}), 4.4\left(2 \times \mathrm{SiMe}_{2}\right)$; HRMS calculated for $\mathrm{C}_{16} \mathrm{H}_{34} \mathrm{O}_{6} \mathrm{SiNa}$ : 373.2021, found 373.2022.

1-Deoxy-2,3,4-trimethoxy-D-mannopyranoside (5). To a solution of 4 (504 mg, $1.44 \mathrm{mmol})$ in $\mathrm{CH}_{3} \mathrm{CN}$ $(6.1 \mathrm{~mL})$ placed under argon atmosphere were added triethylsilane $(0.68 \mathrm{~mL}, 4.3 \mathrm{mmol})$ and TMSOTf $(0.76 \mathrm{~mL}, 4.3 \mathrm{mmol})$. After stirring for $17 \mathrm{~h}, 6 \mathrm{~mL}$ of a saturated solution of $\mathrm{NaHCO}_{3}$ was added and the reaction mixture extracted five times with $8 \mathrm{~mL}$ of $\mathrm{CH}_{2} \mathrm{Cl}_{2}$. The organic solutions were gathered, dried over $\mathrm{Na}_{2} \mathrm{SO}_{4}$, filtered and the solvent was eliminated under reduced pressure. After flash chromatography purification (cyclohexane/ethyl acetate, 100/0 to 0/100, v/v), compound 5 (296 mg, $78 \%$ ) was isolated as a colorless syrup (Scheme 2).

$[\alpha]_{\mathrm{D}}^{20}=-9^{\circ}\left(c=0.17, \mathrm{CH}_{2} \mathrm{Cl}_{2}\right) ; \operatorname{IR}(\mathrm{ATR}): \vee\left(\mathrm{cm}^{-1}\right) 3463,2934,2833,1194,1132,1090,1031,1007,991$, 748; NMR ${ }^{1} \mathrm{H}\left(\mathrm{CD}_{3} \mathrm{OD}, 300 \mathrm{MHz}\right): \delta(\mathrm{ppm}) 4.14\left(\mathrm{dd}, 1 \mathrm{H}, J_{1 \mathrm{a}, 1 \mathrm{~b}}=12.8 \mathrm{~Hz}, J_{1 \mathrm{a}, 2}=2.2 \mathrm{~Hz}, \mathrm{H}_{1 \mathrm{a}}\right), 3.84(\mathrm{dd}$, $\left.1 \mathrm{H}, J_{6 \mathrm{a}, 6 \mathrm{~b}}=11.7 \mathrm{~Hz}, J_{6 \mathrm{a}, 5}=2.9 \mathrm{~Hz}, \mathrm{H}_{6 \mathrm{a}}\right), 3.70\left(\mathrm{dd}, 1 \mathrm{H}, J_{6 \mathrm{~b}, 6 \mathrm{a}}=11.7 \mathrm{~Hz}, J_{6 \mathrm{~b}, 5}=5.5 \mathrm{~Hz}, \mathrm{H}_{6 \mathrm{~b}}\right), 3.61(\mathrm{ddd}$, $\left.1 \mathrm{H}, J_{2,1 \mathrm{a}}=2.0 \mathrm{~Hz}, J_{2,1 \mathrm{~b}}=0.7 \mathrm{~Hz}, \mathrm{H}_{2}\right), 3.53(\mathrm{~s}, 3 \mathrm{H}, \mathrm{OMe}), 3.48(\mathrm{~s}, 3 \mathrm{H}, \mathrm{OMe}), 3.45$ (s, $\left.3 \mathrm{H}, \mathrm{OMe}\right), 3.39$ (d, $\left.1 \mathrm{H}, J_{4,5}=9.4 \mathrm{~Hz}, \mathrm{H}_{4}\right), 3.30\left(\mathrm{dd}, 1 \mathrm{H}, J_{1 \mathrm{~b}, 1 \mathrm{a}}=12.8 \mathrm{~Hz}, J_{1 \mathrm{~b}, 2}=1.0 \mathrm{~Hz}, \mathrm{H}_{1 \mathrm{~b}}\right), 3.25\left(\mathrm{dd}, 1 \mathrm{H}, J_{3,4}=9.3 \mathrm{~Hz}\right.$, $\left.J_{4,2}=3.3 \mathrm{~Hz}, \mathrm{H}_{3}\right), 3.16\left(\mathrm{ddd}, 1 \mathrm{H}, J_{5,4}=9.4 \mathrm{~Hz}, J_{5,6 \mathrm{~b}}=5.5 \mathrm{~Hz}, J_{5,6 \mathrm{a}}=2.9 \mathrm{~Hz}, \mathrm{H}_{5}\right) ; \mathrm{NMR}{ }^{13} \mathrm{C}\left(\mathrm{CD}_{3} \mathrm{OD}\right.$, $75 \mathrm{MHz}): \delta(\mathrm{ppm}) 84.6\left(\mathrm{C}_{5}\right), 80.2,77.0,75.5\left(\mathrm{C}_{2}, \mathrm{C}_{3}, \mathrm{C}_{4}\right), 66.0\left(\mathrm{C}_{6}\right), 62.6\left(\mathrm{C}_{1}\right), 61,0(\mathrm{OMe}), 57.6(\mathrm{OMe})$, 57.4 (OMe); HRMS calculated for $\mathrm{C}_{9} \mathrm{H}_{18} \mathrm{O}_{5} \mathrm{Na}$ : 229.1042, found 229.1052 .

1,6-Dideoxy-2,3,4-trimethoxy-D-mannopyranoside (6). Compound 5 (1.48 g, $7.2 \mathrm{mmol})$ was dissolved in toluene $(30 \mathrm{~mL})$. We successively added triphenylphosphine $(3.32 \mathrm{~g}, 14.4 \mathrm{mmol})$, imidazole $(2.16 \mathrm{~g}, 35.9 \mathrm{mmol})$ and iodine $(3.19 \mathrm{~g}, 14.4 \mathrm{mmol})$. The mixture was stirred at $80^{\circ} \mathrm{C}$ overnight. Solvent was eliminated under a vacuum and the reaction mixture purified by flash chromatography (EtOAc/cyclohexane, 40/60 v/v) yielding to compound $6(1.70 \mathrm{~g}, 74 \%)$ as a yellow powder (Scheme 2).

$[\alpha]_{\mathrm{D}}^{20}=-9^{\circ}\left(c=0.16, \mathrm{CH}_{2} \mathrm{Cl}_{2}\right) ; \operatorname{IR}(\mathrm{ATR}): v\left(\mathrm{~cm}^{-1}\right) 2925,1203,1151,1130,1114,1100,1069,1006,946$, 748; NMR ${ }^{1} \mathrm{H}\left(\mathrm{CD}_{3} \mathrm{OD}, 300 \mathrm{MHz}\right): \delta(\mathrm{ppm}) 4.21\left(\mathrm{dd}, 1 \mathrm{H}, J_{1 \mathrm{a}, 1 \mathrm{~b}}=12.9 \mathrm{~Hz}, J_{1 \mathrm{a}, 2}=2.3 \mathrm{~Hz}, \mathrm{H}_{1 \mathrm{a}}\right), 3.62(\mathrm{~m}$, $\left.1 \mathrm{H}, \mathrm{H}_{2}\right), 3.59(\mathrm{~s}, 3 \mathrm{H}, \mathrm{OMe}), 3.54\left(\mathrm{dd}, 1 \mathrm{H}, \mathrm{J}_{6 \mathrm{a}, 6 \mathrm{~b}}=16.6 \mathrm{~Hz}, J_{6 \mathrm{a}, 5}=2.6 \mathrm{~Hz}, \mathrm{H}_{6 \mathrm{a}}\right), 3.49(\mathrm{~s}, 3 \mathrm{H}, \mathrm{OMe}), 3.46$ (s, $3 \mathrm{H}, \mathrm{OMe}), 3.37-3.21\left(\mathrm{~m}, 4 \mathrm{H}, \mathrm{H}_{6 \mathrm{~b}}, \mathrm{H}_{1 \mathrm{~b}}, \mathrm{H}_{4}, \mathrm{H}_{3}\right), 3.01\left(\mathrm{~m}, 1 \mathrm{H}, \mathrm{H}_{5}\right)$; NMR ${ }^{13} \mathrm{C}\left(\mathrm{CD}_{3} \mathrm{OD}, 75 \mathrm{MHz}\right)$ : $\delta(\mathrm{ppm}) 84.3\left(\mathrm{C}_{3}\right), 80.4\left(\mathrm{C}_{4}\right), 79.4\left(\mathrm{C}_{5}\right), 75.3\left(\mathrm{C}_{2}\right), 65.9\left(\mathrm{C}_{1}\right), 61.4(\mathrm{OMe}), 57.4(2 \times \mathrm{OMe}), 6.8\left(\mathrm{C}_{6}\right)$; HRMS calculated for $\mathrm{C}_{9} \mathrm{H}_{17} \mathrm{IO}_{4} \mathrm{Na}$ : 339.0069 , found 339.0069 .

1,6-Dideoxy-6-(N,N,N-triethylammonium-iodide)-2,3,4-trimethoxy-D-mannopyranoside (M0(TEA)). Triethylamine ( $8.86 \mathrm{~mL}, 63.2 \mathrm{mmol})$ was added to compound $6(1 \mathrm{~g}, 3.16 \mathrm{mmol})$ and the reaction mixture was stirred for four days at $120^{\circ} \mathrm{C}$. After solvent removal, diethyl ether was added and the reaction mixture sonicated for $5 \mathrm{~min}$. After filtration, the solid retrieved was washed using ethyl ether to remove traces of unreacted precursors yielding to M0(TEA) (488 mg, 37\%) as a brown powder (Scheme 2). 
$[\alpha]_{\mathrm{D}}^{20}=-24^{\circ}\left(\mathrm{c}=0.09, \mathrm{CH}_{2} \mathrm{Cl}_{2}\right) ; \mathrm{IR}(\mathrm{ATR}): v\left(\mathrm{~cm}^{-1}\right) 2975,2902,1107,1084 ; \mathrm{NMR}{ }^{1} \mathrm{H}\left(\mathrm{CD}_{3} \mathrm{OD}, 300 \mathrm{MHz}\right):$ $\delta$ (ppm) 4.08-3.95 (m, $\left.3 \mathrm{H}, \mathrm{H}_{1 \mathrm{a}}, \mathrm{H}_{1 \mathrm{~b}}, \mathrm{H}_{2}\right), 3.68-3.09\left(\mathrm{~m}, 10 \mathrm{H}, \mathrm{H}_{3}, \mathrm{H}_{4}, \mathrm{H}_{5}, \mathrm{H}_{6 \mathrm{a}}, \mathrm{H}_{6 \mathrm{~b}}, 3 \times \mathrm{NCH}_{2}\right), 3.54$ (s, $1 \mathrm{H}, \mathrm{OMe}), 3.43(\mathrm{~s}, 1 \mathrm{H}, \mathrm{OMe}), 3.40(\mathrm{~s}, 1 \mathrm{H}, \mathrm{OMe}), 1.32\left(\mathrm{t}, 3 \times 3 \mathrm{H}, \mathrm{J}_{\mathrm{NCH} 2-\mathrm{NCH}}=7.2 \mathrm{~Hz}, \mathrm{NCH}_{3}\right) ; \mathrm{NMR}^{13} \mathrm{C}$ $\left(\mathrm{CD}_{3} \mathrm{OD}, 75 \mathrm{MHz}\right): \delta(\mathrm{ppm})$ 84.1 77.0, 74.8, $\left(\mathrm{C}_{2}, \mathrm{C}_{3}, \mathrm{C}_{4}\right), 72.6\left(\mathrm{C}_{5}\right), 66.1\left(\mathrm{C}_{1}\right), 61.2$, 57.7, $57.0(3 \times \mathrm{OMe})$, $54.6\left(\mathrm{NCH}_{2}\right), 46.6\left(\mathrm{C}_{6}\right), 7.9\left(\mathrm{NCH}_{3}\right) ; \mathrm{MS}(\mathrm{ESI}):\left[\mathrm{M}^{-}\right]=126.1 \mathrm{~m} / z ; \mathrm{HRMS}$ calculated for $\mathrm{C}_{15} \mathrm{H}_{32} \mathrm{NO}_{4}$ : 290.2319, found 290.2331 .

1,6-Dideoxy-6-(1-methyl-1H-imidazol-3-ium iodide)-2,3,4-trimethoxy- $\alpha$-D-mannopyranoside (M0(MII)). N-Methylimidazole $(0.07 \mathrm{~mL}, 0.87 \mathrm{mmol})$ was added to compound $6(0.20 \mathrm{~g}, 0.58 \mathrm{mmol})$ and the reaction mixture stirred for $24 \mathrm{~h}$ at $80^{\circ} \mathrm{C}$. $\mathrm{N}$-methylimidazole was eliminated under a vacuum. The reaction mixture was dispersed into ethyl acetate in ultrasonic bath. The product retrieved yields to M0(MII) (207 mg, 90\%) as a slight yellow syrup (Scheme 2).

$[\alpha]_{\mathrm{D}}^{20}=-26^{\circ}\left(c=0.32, \mathrm{CH}_{2} \mathrm{Cl}_{2}\right) ; \operatorname{IR}(\mathrm{ATR}): v\left(\mathrm{~cm}^{-1}\right) 3458,3088,3041,2938,2894,1575,1180,1143,1097$, 1051, 984, 743; NMR ${ }^{1} \mathrm{H}\left(\mathrm{CDCl}_{3}, 300 \mathrm{MHz}\right): \delta(\mathrm{ppm}) 9.45(\mathrm{~s}, 1 \mathrm{H}, \mathrm{CH}=\mathrm{N}), 7.57,7.37(\mathrm{~s}, 2 \mathrm{H}, 2 \times \mathrm{CH}=\mathrm{CH})$, $4.50\left(\mathrm{dd}, 1 \mathrm{H}, J_{6 \mathrm{a}, 6 \mathrm{~b}}=14.2 \mathrm{~Hz}, J_{6 \mathrm{a}, 5}=1.7 \mathrm{~Hz}, \mathrm{H}_{6 \mathrm{a}}\right), 4.16\left(\mathrm{dd}, 1 \mathrm{H}, J_{6 \mathrm{~b}, 6 \mathrm{a}}=14.2 \mathrm{~Hz}, J_{6 \mathrm{~b}, 5}=9.2 \mathrm{~Hz}, \mathrm{H}_{6 \mathrm{~b}}\right)$, $4.03\left(\mathrm{~m}, 4 \mathrm{H}, \mathrm{H}_{1 \mathrm{a}}, \mathrm{NCH}_{3}\right), 3.47\left(\mathrm{~m}, 2 \mathrm{H}, \mathrm{H}_{2}, \mathrm{H}_{3}\right), 3.43,3.33,3.30\left(\mathrm{~s}, 9 \mathrm{H}, 3 \times \mathrm{OCH}_{3}\right), 3.29\left(\mathrm{~m}, 1 \mathrm{H}, \mathrm{H}_{1 \mathrm{~b}}\right)$, $3.24\left(\mathrm{dd}, 1 \mathrm{H}, J_{3,4}=3.1 \mathrm{~Hz}, J_{4,5}=9.1 \mathrm{~Hz}, \mathrm{H}_{4}\right), 3.05\left(\mathrm{t}, 1 \mathrm{H}, J_{5,6 \mathrm{~b}}=J_{4,5}=9.2 \mathrm{~Hz}, \mathrm{H}_{5}\right) ; \mathrm{NMR}^{13} \mathrm{C}\left(\mathrm{CDCl}_{3}\right.$, $75 \mathrm{MHz}): \delta(\mathrm{ppm}) 136.9(\mathrm{~N}=\mathrm{C}), 123.6(\mathrm{C}=\mathrm{C}), 123.2(\mathrm{C}=\mathrm{C}), 83.6\left(\mathrm{C}_{4}\right), 76.8,76.7\left(\mathrm{C}_{3}, \mathrm{C}_{5}\right), 74.4\left(\mathrm{C}_{2}\right), 65.8$ $\left(\mathrm{C}_{1}\right), 60.9,57.4,56.9(3 \times \mathrm{OMe}), 51.1\left(\mathrm{C}_{6}\right), 37.2(\mathrm{Me}-\mathrm{N})$; MS(ESI): [M- ] = 126.1 m/z; HRMS calculated for $\mathrm{C}_{13} \mathrm{H}_{23} \mathrm{~N}_{2} \mathrm{O}_{4}: 271.1657$, found 271.1658.

6-Deoxy-1,2,3,4-tetramethoxy- $\alpha$-D-glucopyranoside (8). Compound 7 (9.89 g, $41.9 \mathrm{mmol}$ ) was dissolved in toluene $(200 \mathrm{~mL})$. After addition of triphenylphosphine $(22.2 \mathrm{~g}, 83.8 \mathrm{mmol})$, imidazole $(14.3 \mathrm{~g}$, $83.8 \mathrm{mmol})$ and iodine $(21.3 \mathrm{~g}, 83.8 \mathrm{mmol})$, the mixture was stirred overnight at $80{ }^{\circ} \mathrm{C}$. Solvent was eliminated under a vacuum and the reaction mixture purified by flash chromatography (EtOAc/cyclohexane, 30/70 $v / v$ ) yielding to compound 8 (14.5 g, 83\%) as a yellow syrup (Scheme 3).

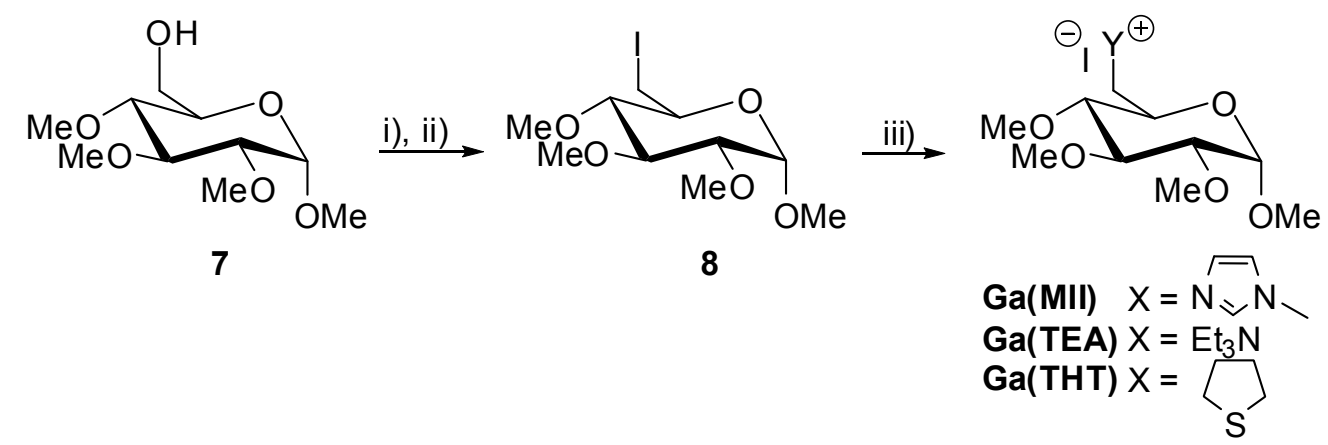

reagents and conditions: i) TBAF, THF $0^{\circ} \mathrm{C}$ to rt., ii) $\mathrm{PPh}_{3}, \mathrm{I}_{2}, \mathrm{C}_{3} \mathrm{H}_{4} \mathrm{~N}_{2}$, toluene, $80^{\circ} \mathrm{C}$, iii) Triethylamine or $\mathrm{N}$-methylimidazole or tetrahydrothiophene $80-120^{\circ} \mathrm{C}$.

Scheme 3. Synthesis of new deoxy anomeric D-glucose derivatives Ga(MII), Ga(TEA) and Ga(THT).

$[\alpha]_{\mathrm{D}}^{20}=+115.9^{\circ}\left(c=2.1, \mathrm{CH}_{2} \mathrm{Cl}_{2}\right) ; \operatorname{IR}(\mathrm{ATR}): v\left(\mathrm{~cm}^{-1}\right) 2984,2931,2907,2832,1465,1444,1412,1374,1327$, 1270, 1186, 1162, 1093, 1084, 978; $\mathrm{NMR}^{1} \mathrm{H}\left(\mathrm{CDCl}_{3}, 300 \mathrm{MHz}\right): \delta(\mathrm{ppm}) 4.79\left(\mathrm{~d}, 1 \mathrm{H}, J_{1,2}=3.6 \mathrm{~Hz}, \mathrm{H}_{1}\right)$, 3.58, 3.57, 3.48, $3.34(\mathrm{~s}, 12 \mathrm{H}, 4 \times \mathrm{OMe}), 3.47\left(\mathrm{~m}, 2 \mathrm{H}, \mathrm{H}_{3}, \mathrm{H}_{6 \mathrm{a}}\right), 3.34-3.27\left(\mathrm{~m}, 2 \mathrm{H}, \mathrm{H}_{5}, \mathrm{H}_{6 \mathrm{~b}}\right), 3.17(\mathrm{~d}, 1 \mathrm{H}$, $\left.J_{2,3}=9.6 \mathrm{~Hz}, \mathrm{H}_{2}\right), 2.93\left(\mathrm{t}, 1 \mathrm{H}, J_{3,4}=J_{4,5}=9.0 \mathrm{~Hz}, \mathrm{H} 4\right) ; \mathrm{NMR}{ }^{13} \mathrm{C}\left(\mathrm{CDCl}_{3}, 75 \mathrm{MHz}\right): \delta(\mathrm{ppm}) 97.4\left(\mathrm{C}_{1}\right)$, 83.3, 83.0, $81.7\left(\mathrm{C}_{2}, \mathrm{C}_{3}, \mathrm{C}_{4}\right), 69.2\left(\mathrm{C}_{5}\right), 60.9(\mathrm{OMe}), 60.8(\mathrm{OMe}), 59.0(\mathrm{OMe}), 55.4(\mathrm{OMe}), 7.5\left(\mathrm{C}_{6}\right)$; HRMS calculated for $\mathrm{C}_{10} \mathrm{H}_{19} \mathrm{IO}_{5} \mathrm{Na}$ : 369.0170, found 369.0175 .

6-Deoxy-6-(1-methyl-1H-imidazol-3-ium-iodide)-1,2,3,4-tetramethoxy- $\alpha$-D-glucopyranoside $\quad(\mathrm{Ga}(\mathrm{MII})$ ). $\mathrm{N}$-Methylimidazole $(0.26 \mathrm{~mL}, 2.3 \mathrm{mmol})$ was added to compound $8(1.02 \mathrm{~g}, 2.9 \mathrm{mmol})$ and the reaction 
mixture stirred for $24 \mathrm{~h}$ at $80^{\circ} \mathrm{C}$ under argon atmosphere. $\mathrm{N}$-methylimidazole was eliminated under a vacuum. Dichloromethane was added to dissolve the reaction mixture and celite was added. After drying under a vacuum, the crude was incorporated into a celite pad and eluted consecutively with a mixture of ethyl acetate and methanol (100/0 to 90/10). The celite was eluted with ethylic ether and dichloromethane. The dichloromethane phase was retrieved and washed a second time with ethyl acetate and dichloromethane, dichloromethane phase was kept and the solvent eliminated under reduced pressure yielding to the compound $\mathrm{Ga}(\mathrm{MII})(925 \mathrm{mg}, 91 \%)$ as a viscous yellow syrup (Scheme 3).

$[\alpha]_{\mathrm{D}}^{20}=+63^{\circ}\left(c=0.16, \mathrm{CH}_{2} \mathrm{Cl}_{2}\right) ; \operatorname{IR}(\mathrm{ATR}): v\left(\mathrm{~cm}^{-1}\right) 3448,3073,2939,2834,1161,1094,1051,987,732 ;$ $\mathrm{NMR}{ }^{1} \mathrm{H}\left(\mathrm{CD}_{3} \mathrm{OD}, 300 \mathrm{MHz}\right): \delta(\mathrm{ppm}) 9.68(\mathrm{~s}, 1 \mathrm{H}, \mathrm{N}=\mathrm{C}), 7.66(\mathrm{t}, 1 \mathrm{H}, \mathrm{CH}=\mathrm{CH}), 7.36(\mathrm{t}, 1 \mathrm{H}, \mathrm{CH}=\mathrm{CH})$, $4.78\left(\mathrm{dd}, 1 \mathrm{H}, J_{1,2}=3.6 \mathrm{~Hz}, \mathrm{H}_{1}\right), 4.54\left(\mathrm{dd}, 1 \mathrm{H}, J_{6 \mathrm{a}, 6 \mathrm{~b}}=14.2 \mathrm{~Hz}, J_{6 \mathrm{a}, 5}=2.6 \mathrm{~Hz}, \mathrm{H}_{6 \mathrm{a}}\right), 4.38(\mathrm{dd}, 1 \mathrm{H}$, $\left.J_{6 \mathrm{a}, 6 \mathrm{~b}}=14.2 \mathrm{~Hz}, J_{6 \mathrm{~b}, 5}=7.1 \mathrm{~Hz}, \mathrm{H}_{6 \mathrm{~b}}\right), 4.11\left(\mathrm{~s}, 3 \mathrm{H}, \mathrm{NCH}_{3}\right), 3.70\left(\mathrm{ddd}, 1 \mathrm{H}, J_{6 \mathrm{a}, 5}=2.6 \mathrm{~Hz}, J_{6 \mathrm{~b}, 5}=7.1 \mathrm{~Hz}\right.$, $\left.J_{5,4}=9.4 \mathrm{~Hz}, \mathrm{H}_{5}\right), 3.52(\mathrm{~s}, 3 \mathrm{H}, \mathrm{OMe}), 3.50(\mathrm{~s}, 3 \mathrm{H}, 3 \mathrm{H}, \mathrm{OMe}), 3.47-3.35\left(\mathrm{~m}, 1 \mathrm{H}, \mathrm{H}_{3}\right), 3.42(\mathrm{~s}, 3 \mathrm{H}, \mathrm{OMe})$, $3.19 \mathrm{~s}, 3 \mathrm{H}, \mathrm{OMe}), 3.11\left(\mathrm{dd}, 1 \mathrm{H}, J_{1,2}=3.6 \mathrm{~Hz}, \mathrm{H}_{2}\right), 2.74\left(\mathrm{dd}, 1 \mathrm{H}, J_{5,4}=9.8 \mathrm{~Hz}, \mathrm{H}_{4}\right)$; NMR ${ }^{13} \mathrm{C}\left(\mathrm{CD}_{3} \mathrm{OD}\right.$, $75 \mathrm{MHz}): \delta(\mathrm{ppm}) 137.7(\mathrm{~N}=\mathrm{C}), 124.0,122.9(\mathrm{CH}=\mathrm{CH}, \mathrm{CH}=\mathrm{CH}), 97.6\left(\mathrm{C}_{1}\right), 82.9\left(\mathrm{C}_{3}\right), 81.4\left(\mathrm{C}_{2}\right), 79.7\left(\mathrm{C}_{4}\right)$, $68.5\left(\mathrm{C}_{5}\right), 60.5(2 \times \mathrm{OMe}), 59.0(\mathrm{OMe}), 55.9(\mathrm{OMe}), 50.8\left(\mathrm{C}_{6}\right), 37.5\left(\mathrm{NCH}_{3}\right) ; \mathrm{MS}(\mathrm{ESI}):\left[\mathrm{M}^{-}\right]=126.1 \mathrm{~m} / \mathrm{z}$; HRMS calculated for $\mathrm{C}_{14} \mathrm{H}_{25} \mathrm{~N}_{2} \mathrm{O}_{5}: 301.1760$, found 301.1763 .

6-Deoxy-6-(N,N,N-triethylammonium-iodide)-1,2,3,4-tetramethoxy- $\alpha$-D-glucopyranoside $\quad$ (Ga(TEA)). Triethylamine (24.28 mL, $173.4 \mathrm{mmol})$ was added to compound $8(3 \mathrm{~g}, 8.67 \mathrm{mmol})$ and the reaction mixture stirred for four days at $120^{\circ} \mathrm{C}$. After removing the solvent, diethyl ether was added and the reaction mixture sonicated for $5 \mathrm{~min}$. After filtration, the solid was washed with ethyl ether to remove traces of unreacted starting material yielding to $\mathrm{Ga}(\mathrm{TEA})(3.10 \mathrm{~g}, 80 \%)$ as a light yellow powder (Scheme 3).

$[\alpha]_{\mathrm{D}}^{20}=+120^{\circ}\left(c=0.16, \mathrm{CH}_{2} \mathrm{Cl}_{2}\right) ; \operatorname{IR}(\mathrm{ATR}): \vee\left(\mathrm{cm}^{-1}\right) 2924,2834,1465,1445,1163,1095,1068,1058,1040$, 1026, 996, 909, 743; NMR ${ }^{1} \mathrm{H}\left(\mathrm{CD}_{3} \mathrm{OD}, 300 \mathrm{MHz}\right): \delta(\mathrm{ppm}) 4.72\left(\mathrm{~m}, 1 \mathrm{H}, \mathrm{H}_{2}\right), 3.79\left(\mathrm{~m}, 1 \mathrm{H}, \mathrm{H}_{5}\right), 3.75-3.27$ $\left(\mathrm{m}, 18 \mathrm{H}, 4 \times \mathrm{OCH}_{3}, \mathrm{H}_{6 \mathrm{a}}, \mathrm{H}_{6 \mathrm{~b}}, \mathrm{H}_{3}, 3 \times \mathrm{NCH}_{2}\right), 3.13\left(\mathrm{~m}, 1 \mathrm{H}, \mathrm{H}_{2}\right), 2.95\left(\mathrm{~m}, 1 \mathrm{H}, \mathrm{H}_{4}\right), 1.35\left(\mathrm{~m}, 9 \mathrm{H}, \mathrm{NCH}_{3}\right)$; $\mathrm{NMR}^{13} \mathrm{C}\left(\mathrm{CD}_{3} \mathrm{OD}, 75 \mathrm{MHz}\right): \delta(\mathrm{ppm}) 98.5\left(\mathrm{C}_{1}\right), 83.0\left(\mathrm{C}_{3}\right), 80.9\left(\mathrm{C}_{2}\right), 80.2\left(\mathrm{C}_{4}\right), 65.7\left(\mathrm{C}_{5}\right), 61.4(\mathrm{OMe}), 60.7$ (OMe), $59.3(\mathrm{OMe}), 58.8\left(\mathrm{C}_{6}\right), 57.7(\mathrm{OMe}), 54.7\left(3 \times \mathrm{NCH}_{2}\right), 8.1\left(3 \times \mathrm{NCH}_{3}\right)$; MS(ESI): [M-] = $126.1 \mathrm{~m} / z$; HRMS calculated for $\mathrm{C}_{16} \mathrm{H}_{34} \mathrm{NO}_{5}$ : 320.2432 , found 320.2437 .

6-Deoxy-6-(tetrahydro-1H-thiophen-1-ium-iodide)-1,2,3,4-trimethoxy- $\alpha$-D-glucopyranoside $\quad$ (Ga(THT)). Triethylamine $(15.29 \mathrm{~mL}, 173.4 \mathrm{mmol})$ was added to compound 8 ( $3 \mathrm{~g}, 8.67 \mathrm{mmol})$ and the reaction mixture stirred for four days at $120^{\circ} \mathrm{C}$. After removing the solvent, diethyl ether was added and the reaction mixture sonicated for $5 \mathrm{~min}$. After filtration, the solid was washed with ethyl ether to remove traces of unreacted precursors yielding to $\mathrm{Ga}$ (THT) $(0.200 \mathrm{~g}, 6 \%)$ as a beige powder (Scheme 3 ).

$[\alpha]_{\mathrm{D}}^{20}=+87^{\circ}\left(c=0.140, \mathrm{CH}_{2} \mathrm{Cl}_{2}\right) ; \operatorname{IR}(\mathrm{ATR}): v\left(\mathrm{~cm}^{-1}\right) 2910.8,2836.2,1158.3,1093.2,1066.3,1945.6,1018.1$, 988.5, 967.8; $\mathrm{NMR}^{1} \mathrm{H}\left(\mathrm{CD}_{3} \mathrm{OD}, 300 \mathrm{MHz}\right): \delta(\mathrm{ppm}) 4.77$ (d, $\left.\left.1 \mathrm{H}, J_{1,2}=3.5 \mathrm{~Hz}\right), \mathrm{H}_{1}\right), 4.06-3.67(\mathrm{~m}, 7 \mathrm{H}$, $\left.\mathrm{H}_{5}, \mathrm{H}_{6 \mathrm{a}}, \mathrm{H}_{6 \mathrm{~b}}, 2 \times \mathrm{CH}_{2}\right), 3.62-3.37\left(\mathrm{~m}, 2 \mathrm{H}, \mathrm{H}_{3}, \mathrm{H}_{4}\right), 3.59$ (s, $\left.3 \mathrm{H}, \mathrm{OMe}\right), 3.55$ (s, $\left.3 \mathrm{H}, \mathrm{OMe}\right), 3.47(\mathrm{~s}, 3 \mathrm{H}$, $\mathrm{OMe}), 3.43(\mathrm{~s}, 3 \mathrm{H}, \mathrm{OMe}), 3.22-3.05\left(\mathrm{~m}, 1 \mathrm{H}, \mathrm{H}_{2}\right), 2.71-1.56\left(\mathrm{~m}, 4 \mathrm{H}, 2 \times \mathrm{CH}_{2} \mathrm{~S}\right)$; $\mathrm{NMR}^{13} \mathrm{C}\left(\mathrm{CD}_{3} \mathrm{OD}\right.$, $75 \mathrm{MHz}): \delta(\mathrm{ppm}) 98.2\left(\mathrm{C}_{1}\right), 82.9,81.9,81.5\left(\mathrm{C}_{2}, \mathrm{C}_{3}, \mathrm{C}_{4}\right), 67.5\left(\mathrm{C}_{5}\right), 61.1(\mathrm{OMe}), 60.9(\mathrm{OMe}), 59.4(\mathrm{OMe})$, $56.5(\mathrm{OMe}), 46.3\left(\mathrm{CH}_{2}\right), 46.2\left(\mathrm{CH}_{2}\right), 44.8\left(\mathrm{C}_{6}\right), 29.45\left(\mathrm{CH}_{2} \mathrm{~S}\right), 29.3\left(\mathrm{CH}_{2} \mathrm{~S}\right) ; \mathrm{MS}(\mathrm{ESI}):\left[\mathrm{M}^{-}\right]=126.1 \mathrm{~m} / z$; HRMS calculated for $\mathrm{C}_{14} \mathrm{H}_{27} \mathrm{SO}_{5}: 307.1579$, found 307.1588 .

Acknowledgments: The authors wish to thank Vittoria Novelli for fruitful discussions on EIS measurements and their interpretation, and Matthieu Courty for TGA and calorimetric analysis. We also acknowledge the Conseil Régional de Picardie and FEDER for their financial support of ROBUST and CONCERTO research programs.

Author Contributions: GH and ANVH performed the synthesis. IS and GH carried out the cell assembly and measurements. GH and FS performed the electrochemical measurements. ANVH and FS supervised the work. 
Conflicts of Interest: The authors declare no conflict of interest.

\section{References}

1. Green, M.A. Third Generation Photovoltaics: Advanced Solar Energy Conversion; Springer: Berlin, Germany, 2006; Volume 12.

2. Lewis, N.S. Toward cost-effective solar energy use. Science 2007, 315, 798-801. [CrossRef] [PubMed]

3. Schiermeier, Q.; Tollefson, J.; Scully, T.; Witze, A.; Morton, O. Energy alternatives: Electricity without carbon. Nat. News 2008, 454, 816-823. [CrossRef] [PubMed]

4. World Energy Outlook; International Energy Agency: Paris, France, 2013.

5. Grätzel, M. Solar energy conversion by dye-sensitized photovoltaic cells. Inorg. Chem. 2005, 44, 6841-6851. [CrossRef] [PubMed]

6. O'Regan, B.; Grätzel, M. A low-cost, high-efficiency solar cell based on dye-sensitized colloidal $\mathrm{TiO}_{2}$ films. Nature 1991, 353, 737-740. [CrossRef]

7. Nazeeruddin, M.K.; Kay, A.; Rodicio, I.; Humphry-Baker, R.; Müller, E.; Liska, P.; Vlachopoulos, N.; Grätzel, M. Conversion of light to electricity by cis-X2bis (2,2'-bipyridyl-4, 4'-dicarboxylate)ruthenium(II) charge-transfer sensitizers $\left(\mathrm{X}=\mathrm{Cl}^{-}, \mathrm{Br}^{-}, \mathrm{I}^{-}, \mathrm{CN}^{-}\right.$, and $\left.\mathrm{SCN}^{-}\right)$on nanocrystalline titanium dioxide electrodes. J. Am. Chem. Soc. 1993, 115, 6382-6390. [CrossRef]

8. Kakiage, K.; Aoyama, Y.; Yano, T.; Oya, K.; Fujisawa, J.; Hanaya, M. Highly-efficient dye-sensitized solar cells with collaborative sensitization by silyl-anchor and carboxy-anchor dyes. Chem. Commun. 2015, 51, 15894-15897. [CrossRef] [PubMed]

9. Sauvage, F.; Chhor, S.; Marchioro, A.; Moser, J.-E.; Graetzel, M. Butyronitrile-based electrolyte for dye-sensitized solar cells. J. Am. Chem. Soc. 2011, 133, 13103-13109. [CrossRef] [PubMed]

10. Yu, Q.; Zhou, D.; Shi, Y.; Si, X.; Wang, Y.; Wang, P. Stable and efficient dye-sensitized solar cells: Photophysical and electrical characterizations. Energy Environ. Sci. 2010, 3, 1722-1725. [CrossRef]

11. Marszalek, M.; Arendse, F.D.; Decoppet, J.-D.; Babkair, S.S.; Ansari, A.A.; Habib, S.S.; Wang, M.; Zakeeruddin, S.M.; Grätzel, M. Ionic Liquid-Sulfolane Composite Electrolytes for High-Performance and Stable Dye-Sensitized Solar Cells. Adv. Energy Mater. 2014, 4, 1301235-1301242. [CrossRef]

12. Stergiopoulos, T.; Kontos, A.G.; Jiang, N.; Milliken, D.; Desilvestro, H.; Likodimos, V.; Falaras, P. High boiling point solvent-based dye solar cells pass a harsh thermal ageing test. Sol. Energy Mater. Sol. Cells 2016, 144, 457-466. [CrossRef]

13. Zakeeruddin, S.M.; Graetzel, M. Solvent-Free Ionic Liquid Electrolytes for Mesoscopic Dye-Sensitized Solar Cells. Adv. Funct. Mater. 2009, 19, 2187-2202. [CrossRef]

14. Lee, C.-P.; Chen, P.-Y.; Ho, K.-C. Ionic Liquid Based Electrolytes for Dye-Sensitized Solar Cells, Ionic Liquids: Theory, Properties, New Approaches; InTech: Rijeka, Croatia, 2011.

15. Wyss, P.; Moehl, T.; Zakeeruddin, S.M.; Grätzel, M. Influence of cations of the electrolyte on the performance and stability of dye sensitized solar cells. J. Mater. Chem. 2012, 22, 24424-24429. [CrossRef]

16. Strappaveccia, G.; Ismalaj, E.; Petrucci, C.; Lanari, D.; Marrocchi, A.; Drees, M.; Facchetti, A.; Vaccaro, L. A biomass-derived safe medium to replace toxic dipolar solvents and access cleaner Heck coupling reactions. Green Chem. 2015, 17, 365-372. [CrossRef]

17. Ghavre, M.; Byrne, O.; Altes, L.; Surolia, P.K.; Spulak, M.; Quilty, B.; Thampi, K.R.; Gathergood, N. Low toxicity functionalised imidazolium salts for task specific ionic liquid electrolytes in dye-sensitised solar cells: a step towards less hazardous energy production. Green Chem. 2014, 16, 2252-2265. [CrossRef]

18. Kuang, D.; Klein, C.; Ito, S.; Moser, J.-E.; Humphry-Baker, R.; Evans, N.; Duriaux, F.; Graetzel, C.; Zakeeruddin, S.M.; Grätzel, M. High-Efficiency and Stable Mesoscopic Dye-Sensitized Solar Cells Based on a High Molar Extinction Coefficient Ruthenium Sensitizer and Nonvolatile Electrolyte. Adv. Mater. 2007, 19, 1133-1137. [CrossRef]

19. Wilkes, J.S. A short history of ionic liquids-From molten salts to neoteric solvents. Green Chem. 2002, 4, 73-80. [CrossRef]

20. Mudring, A.-V. Solidification of ionic liquids: Theory and techniques. Aust. J. Chem. 2010, 63, 544-564. [CrossRef]

21. Wu, J.; Lan, Z.; Lin, J.; Huang, M.; Huang, Y.; Fan, L.; Luo, G. Electrolytes in Dye-Sensitized Solar Cells. Chem. Rev. 2015, 115, 2136-2173. [CrossRef] [PubMed] 
22. Ue, M.; Ida, K.; Mori, S. Electrochemical Properties of Organic Liquid Electrolytes Based on Quaternary Onium Salts for Electrical Double-Layer Capacitors. J. Electrochem. Soc. 1994, 141, 2989-2996. [CrossRef]

23. Kambe, S.; Nakade, S.; Kitamura, T.; Wada, Y.; Yanagida, S. Influence of the electrolytes on electron transport in mesoporous $\mathrm{TiO}_{2}$-electrolyte systems. J. Phys. Chem. B 2002, 106, 2967-2972. [CrossRef]

24. Son, K.M.; Kang, M.G.; Vittal, R.; Lee, J.; Kim, K.-J. Effects of substituents of imidazolium cations on the performance of dye-sensitized $\mathrm{TiO}_{2}$ solar cells. J. Appl. Electrochem. 2008, 38, 1647-1652. [CrossRef]

25. Wang, M.; Chen, P.; Humphry-Baker, R.; Zakeeruddin, S.M.; Grätzel, M. The Influence of Charge Transport and Recombination on the Performance of Dye-Sensitized Solar Cells. ChemPhysChem 2009, 10, 290-299. [CrossRef] [PubMed]

26. Flasque, M.; Van Nhien, A.N.; Swiatowska, J.; Seyeux, A.; Davoisne, C.; Sauvage, F. Interface Stability of a $\mathrm{TiO}_{2}$ /3-Methoxypropionitrile-Based Electrolyte: First Evidence for Solid Electrolyte Interphase Formation and Implications. ChemPhysChem 2014, 15, 1126-1137. [CrossRef] [PubMed]

27. Cao, Y.; Bai, Y.; Yu, Q.; Cheng, Y.; Liu, S.; Shi, D.; Gao, F.; Wang, P. Dye-sensitized solar cells with a high absorptivity ruthenium sensitizer featuring a 2-(hexylthio) thiophene conjugated bipyridine. J. Phys. Chem. C 2009, 113, 6290-6297. [CrossRef]

28. Peter, L.M. Dye-sensitized nanocrystalline solar cells. Phys. Chem. Chem. Phys. 2007, 9, 2630-2642. [CrossRef] [PubMed]

29. O'Regan, B.; Durrant, J.R.; Sommeling, P.M.; Bakker, N.J. Influence of the $\mathrm{TiCl}_{4}$ treatment on nanocrystalline $\mathrm{TiO}_{2}$ films in dye-sensitized solar cells. 2. Charge density, band edge shifts, and quantification of recombination losses at short circuit. J. Phys. Chem. C 2007, 111, 14001-14010.

30. Bisquert, J.; Fabregat-Santiago, F.; Mora-Seró, I.; Garcia-Belmonte, G.; Giménez, S. Electron lifetime in dye-sensitized solar cells: Theory and interpretation of measurements. J. Phys. Chem. C 2009, 113, 17278-17290. [CrossRef]

31. Ito, S.; Murakami, T.N.; Comte, P.; Liska, P.; Grätzel, C.; Nazeeruddin, M.K.; Grätzel, M. Fabrication of thin film dye sensitized solar cells with solar to electric power conversion efficiency over $10 \%$. Thin Solid Films 2008, 516, 4613-4619. [CrossRef]

32. Hauch, A.; Georg, A. Diffusion in the electrolyte and charge-transfer reaction at the platinum electrode in dye-sensitized solar cells. Electrochim. Acta 2001, 46, 3457-3466. [CrossRef]

33. Fabregat-Santiago, F.; Bisquert, J.; Garcia-Belmonte, G.; Boschloo, G.; Hagfeldt, A. Influence of electrolyte in transport and recombination in dye-sensitized solar cells studied by impedance spectroscopy. Sol. Energy Mater. Sol. Cells 2005, 87, 117-131.

34. Fabregat-Santiago, F.; Bisquert, J. Dye-Sensitized Solar Cells; EPFL Press: Lausanne, Switzerland, 2010.

35. Poletti, L.; Chiappe, C.; Lay, L.; Pieraccini, D.; Polito, L.; Russo, G. Glucose-derived ionic liquids: Exploring low-cost sources for novel chiral solvents. Green Chem. 2007, 9, 337-341. [CrossRef]

36. El-Badri, M.H.; Willenbring, D.; Tantillo, D.J.; Gervay-Hague, J. Mechanistic studies on the stereoselective formation of $\beta$-mannosides from mannosyl iodides using $\alpha$-deuterium kinetic isotope effects. J. Org. Chem. 2007, 72, 4663-4672. [CrossRef] [PubMed]

37. Boultadakis-Arapinis, M.; Prost, E.; Gandon, V.; Lemoine, P.; Turcaud, S.; Micouin, L.; Lecourt, T. Carbene-Mediated Functionalization of the Anomeric C-H Bond of Carbohydrates: Scope and Limitations. Chem. Eur. J. 2013, 19, 6052-6066. [CrossRef] [PubMed]

(C) 2016 by the authors; licensee MDPI, Basel, Switzerland. This article is an open access article distributed under the terms and conditions of the Creative Commons by Attribution (CC-BY) license (http://creativecommons.org/licenses/by/4.0/). 